\title{
New Information on Lending to Small Businesses and Small Farms: The 1996 CRA Data
}

Raphael W. Bostic and Glenn B. Canner, of the Board's Division of Research and Statistics, prepared this article. Sheryl L. Hudson and John E. Matson provided research assistance.

The Community Reinvestment Act (CRA) of 1977 is intended to encourage commercial banks and savings associations to help meet the credit needs of their local communities in a manner consistent with safe and sound banking practices. As a consequence of recent revisions to the regulations that implement the CRA, new information is now publicly available on the geographic distribution of small loans to businesses and farms and on community development lending. Because small businesses and small farms are more likely than larger ones to borrow small amounts, the CRA data on small loans are likely to provide a reasonable measure of the extension of credit to such businesses (and hence, in this article, inferences about lending to small businesses and small farms are based on data on small loans).

The new CRA data, combined with information reported by institutions about the geographic areas that constitute their local communities, enable lenders, supervisory agencies, and members of the public to better assess the performance of these institutions in meeting their CRA obligations. Just as the availability of credit to purchase, refinance, and improve homes is critical to the well-being of local communities, so is the availability of credit for small businesses and small farms. The new CRA data thus complement information made available pursuant to the Home Mortgage Disclosure Act (HMDA) about the flow of housing-related credit to communities nationwide. ${ }^{1}$ The CRA data also provide new opportunities to gauge the flow of credit to com-

1. HMDA data have been available for many years and have been widely analyzed. Research based on HMDA data has found that the flow of mortgage credit varies with characteristics of borrowers and local neighborhoods. See Glenn B. Canner and Dolores S. Smith, "Home Mortgage Disclosure Act: Expanded Data on Residential Lending," Federal Reserve Bulletin, vol. 77 (November 1991), pp. 859-81; and Glenn B. Canner and Wayne Passmore, "Home Purchase Lending in Low-Income Neighborhoods and to Low-Income Borrowers," Federal Reserve Bulletin, vol. 81 (February 1995), pp. 71-103. munities with differing economic and demographic characteristics.

Although intended primarily to facilitate assessments of performance under the CRA, the data on small business and small farm lending are likely to be used in other ways as well. For example, lending institutions may use the data to help evaluate the effectiveness of products and services and to calculate their share of the small business loan market in a given geographic area. Similarly, the federal agencies charged with enforcing the nation's antitrust laws may use the CRA data in assessing the competitive effects of bank mergers and acquisitions.

This article presents an initial assessment of the new CRA data on originations and purchases of small business and small farm loans during 1996. It is mainly intended to provide a description of the depth and breadth of the data and to place the information in the context in which it will be used for CRA and other regulatory enforcement activities. The focus of the analysis is on the broad patterns that emerge when the data are reviewed from a national perspective rather than on the lending activities of any individual institution. The article also discusses some of the important limitations of the data and challenges that arise in using this new information.

For 1996, we find that nearly 2,100 large commercial banks and savings associations (savings banks and savings and loan associations) reported data on their small business, small farm, and community development lending and on the geographic areas that constitute their local communities. ${ }^{2}$ While they account for only 18 percent of all commercial banks and savings associations, the CRA reporters extend about two-thirds of all small business loans and about one-fifth of all small farm loans granted by such institutions. Of the CRA reporters that extended loans, the most active 1 percent granted a large proportion (nearly half) of the small business loans and 13 percent of the small farm loans.

Like the number of businesses and farms, the distribution of lending to small businesses and small

2. The regulation implementing the CRA requires only large commercial banks and savings associations to report their lending activity. 
farms varies geographically. Most small business loans are extended in central city and suburban areas; most small farm loans, not surprisingly, are in rural areas. Overall, the distribution of small business lending across census tracts categorized by their income generally follows the distribution of the population and businesses across these areas. Within central city areas, the data show that most small business loans are extended in areas with low home-ownership rates - areas that tend to have high concentrations of businesses. About half of the CRA reporters extended community development loans, which tended to be much larger in size than the average small business or small farm loan.

\section{ORIGINS OF THE NEW DATA REPORTING REQUIREMENTS ON SMALL BUSINESS AND SMALL FARM LENDING}

The CRA was enacted two decades ago in response to the concern that many commercial banks and savings associations were thought to be accepting deposits from households and firms in inner cities while lending and investing them primarily elsewhere. These "disinvestment" activities, it was maintained, were contributing to the decline of many urban areas as evidenced by a deterioration in the quality of housing in these areas and a shift of jobs to surrounding areas. In adopting the CRA, the Congress reaffirmed the principle that commercial banks and savings associations have an obligation under their charters to serve the "convenience and needs" of their local communities by providing credit services to all segments of those communities. For purposes of enforcement, the supervisory agencies are directed to periodically assess the performance of institutions in this regard, to make available to the public written evaluations, including CRA performance ratings, and to consider the institution's record in acting on applications for deposit facilities, mergers, and acquisitions. ${ }^{3}$

\section{Evolution of CRA Regulation}

Historically, CRA performance evaluations focused on the processes used and efforts made by institutions to serve their local communities as well as on the

3. The supervisory agencies are the Board of Governors of the Federal Reserve System, the Federal Deposit Insurance Corporation, the Office of the Comptroller of the Currency, and the Office of Thrift Supervision. results of those efforts. This approach to CRA assessments was heavily criticized, both by community organizations and lending institutions. Community organizations argued that the examination process failed to make meaningful distinctions between institutions that performed well and those that performed poorly. Lenders contended that CRA enforcement was too focused on process and paperwork and that the examination standards were unclear and inconsistently applied. In response to these concerns, President Clinton in July 1993 asked the supervisory agencies to reform the regulations that implement the CRA. ${ }^{4}$

The agencies subsequently adopted revised regulations in May 1995 that were intended to make CRA assessments more performance-based, more objective, and less burdensome for covered institutions. The new regulations substitute three performance tests-lending, investment, and service-for the twelve assessment factors contained in the original regulation. ${ }^{5}$ (See the box "The Three CRA Performance Tests.")

In assessing compliance with the CRA, the three performance tests are evaluated in the context of information about the institution and its community, competitors, and peers. For example, CRA assessments consider the economic and demographic characteristics of the local service areas; lending, investment, and service opportunities in the local community; the institution's product offerings and business strategy; and its capacity and constraints. ${ }^{6}$

\section{Lending to Small Businesses and Small Farms}

Although data collection efforts in support of CRA enforcement have traditionally focused on home mortgage lending, a consensus has evolved in recent years that lending to small businesses and small farms is also critical for a vital and viable community. Responding to this recognition, one of the more significant changes to the regulation requires commercial banks and savings associations defined as

4. For a discussion of the original regulation and concerns that led to the revised regulation, see Griffith L. Garwood and Dolores S. Smith, "The Community Reinvestment Act: Evolution and Current Issues," Federal Reserve Bulletin, vol. 79 (April 1993), pp. 251-67. For a discussion of the new regulation and the regulatory alternatives considered before its adoption, see the Federal Reserve's press release on the new CRA regulations, April 24, 1995.

5. For a description of the original twelve assessment factors, see Garwood and Smith, "The Community Reinvestment Act," p. 253.

6. For further details, see the Federal Reserve press release, April 24, 1995, and Kevin T. Kane, "CRA's More Flexible Yardstick," Mortgage Banking (September 1997), pp. 54-60. 


\section{The Three CRA Performance Tests}

The regulations that implement the CRA set forth three tests by which the performance of covered institutions will be evaluated: a lending test, an investment test, and a service test.

The lending test involves the measurement of lending activity for a variety of loan types, including small business and small farm loans. Among the assessment criteria are the geographic distribution of lending, the distribution of lending across different types of borrowers, the extent of community development lending, and the use of innovative or flexible lending practices to address the credit needs of low- or moderate-income individuals or areas.

The investment test considers the extent of an institution's involvement with qualified investments. A qualified investment is an investment, deposit, or grant that benefits the institution's assessment area or a broader statewide or regional area that includes its assessment area.

The service test considers the availability and responsiveness of an institution's system for delivering retail banking services and judges the extent of its community development services and their degree of innovation. Among the assessment criteria are the geographic distribution of an institution's branches and automated teller machines, the availability of alternative systems for delivering retail banking services in low- and moderateincome areas and to low- and moderate-income persons, and the provision of community development services.

"large" under the regulation to collect and report data annually on the number and dollar amount of their originations and purchases of small loans to businesses and farms and any community development loans. Only independent institutions with total assets of $\$ 250$ million or more and institutions of any size if owned by a holding company that has assets of $\$ 1$ billion or more are subject to the new data reporting requirements.

For purposes of reporting, small loans to businesses and farms are grouped in two ways. First, loans are reported in three loan size categories based on the original amount of the loan: $\$ 100,000$ or less, $\$ 100,001$ to $\$ 250,000$, and more than $\$ 250,000 .^{7}$ For businesses, the maximum loan size reported is $\$ 1$ million; for farms, the maximum is $\$ 500,000$. Second, these loans are categorized according to the

7. For lines of credit, the reported amount is the size of the line at the time of origination. geographic location (census tract or block numbering area) of the firms and farms receiving them. Unlike the business and farm loans, no geographic information is provided for community development loans; only the aggregate amount of lending by each institution is reported.

The data also include information on how many of the reported loans were extended to businesses and farms with annual revenues of $\$ 1$ million or less. Such firms fall within generally accepted definitions of a small business, although somewhat larger firms are also often categorized as being a small business or small farm. ${ }^{8}$ Finally, each reporting institution includes a list of the areas that constitute its local CRA assessment community. For a small institution, the assessment area may be a single, relatively small geographic area; a large institution may have many assessment areas, some small and some large, which in some cases span the country.

The data on business and farm lending reported under the CRA regulations are more limited in scope than data reported on home lending under HMDA. In particular, the CRA data include information only on loans originated or purchased, not on applications that are turned down or withdrawn by the customer. Also, unlike HMDA data, the CRA data do not include the income, sex, or racial or ethnic background of applicants. Finally, the CRA data are not reported and disclosed application by application as HMDA data are; rather the data are aggregated into the three loan size categories and then reported at the census tract level.

From the information submitted by reporting institutions, the Federal Financial Institutions Examination Council (FFIEC) prepares a disclosure statement for each institution, in electronic form, as well as an aggregate statement for each of the 332 metropolitan statistical areas (MSAs) and each of the nonmetropolitan counties in the United States and Puerto Rico. Before public release of the CRA data, the FFIEC and the supervisory agencies review it to help ensure its accuracy (see the box "Data Quality"). The FFIEC made the CRA data on 1996 lending activity available to the public in October $1997 .{ }^{9}$ For more information on the content of these disclosures and how to obtain the new CRA data, see the box "CRA Disclosures."

8. According to the 1993 National Survey of Small Business Finances, sponsored by the Federal Reserve Board and the U.S. Small Business Administration, about 84 percent of all small businesses (defined as having fewer than 500 full-time employees) have annual revenues of less than $\$ 1$ million.

9. See the FFIEC press release, September 30, 1997. 


\section{Data Quality}

To maximize the usefulness of the CRA data, the information must be accurate and made available to the public on a timely basis. To achieve these objectives, the reporting institutions and their supervisory agencies have made a substantial commitment of resources.

The supervisory agencies seek to ensure that the commercial banks and savings associations they supervise provide complete and accurate information. To facilitate accurate reporting, the FFIEC makes available tools and information to assist covered institutions through the CRA site on its World Wide Web home page (http://www.ffiec.gov) and in various hard copy forms. The FFIEC Web site for the CRA, for example, includes the regulation, instructions on how to file data reports, a description of which institutions are covered by the data reporting requirements, the text of interagency interpretive letters pertaining to the regulation and interagency questions, and answers to the most frequently asked questions about compliance. The CRA site also includes a geocoding system that allows anyone to identify the census tract that corresponds to a specific street address.

Beyond informational tools, the FFIEC makes available an electronic data entry and reporting system that incorporates a series of edit routines to detect and correct errors in the data. In addition, the FFIEC reviews each reporting institution's CRA data before public release and subjects the data to further quality checks. Finally, the supervisory agencies conduct on-site examinations and periodically review the covered institutions' compliance with the geographic reporting requirements of the regulation. Such reviews consider, for example, the accuracy of the geocoding done by reporters and the completeness of their filings.

\section{CHALLENGES AND LIMITATIONS}

Whether the new CRA data are used to help gauge an institution's record with respect to the CRA or for other purposes, the nature of the information and limits on information that can be used in conjunction with the new data pose many challenges for analysts. Challenges arise because reporting rules and limits on information available to the reporting institutions create the potential for incorrect interpretations. Analysts also face challenges because the census data used to characterize neighborhoods and to assess the distribution of lending are collected only every ten years. Finally, an appropriate interpretation of the CRA data requires an understanding of the different demand and supply conditions that prevail across local markets.

10. The same issue arises in assessing HMDA data on home lending. For home refinancing and, in some cases, home improvement loans, the funds may be used to support activity in a location that is not the same as that of the property. For home purchase lending, however, the HMDA data include the location of the property to be purchased (with some minor exceptions), and consequently the appro-

priateness of the census tract categorization is generally not an issue.

Under the CRA, lending institutions are asked to report the geographic location of the business or farm receiving the loan. According to the rules for such "geocoding," institutions may designate the location of the loan as being either the location of the business headquarters or the primary area where the loan proceeds are applied. For firms with operations in multiple locations, the potential for incorrect interpretations of data arises because some or all of the funds may be used to support activities in locations not reported by the lender. Thus, assessments of the data may characterize a loan by the economic and demographic characteristics of a reported location (the census tract of the headquarters) even though the funds are used to support the activities of the business or farm in a location with different characteristics. Unfortunately, it is not possible to identify the extent to which the geographic locations reported in the data reflect where loan funds are actually used. ${ }^{10}$

The potential for this type of census tract miscategorization does not appear to be large, however. Information from the 1993 National Survey of Small Business Finances indicates that most small businesses have few offices. According to the survey, 84 percent of small businesses have only one office and 95 percent have two or fewer offices. In addition, the effects of such miscategorization are likely to be small, as the data are not considered in isolation for CRA performance evaluations. Other information, such as documentation in loan files, may be available to help examiners determine whether the census tract categorization provided by the lender is appropriate.

\section{Post Office Boxes and Rural Routes}

Another issue, also related to the proper geographic categorization of small business and small farm lending, arises when the street address of a business or farm is not used by a lender to identify the location of the firm or farm. This situation occurs when a street address is not available to the lender because the firm or farm provided only a post office box number or a rural route or box number. 


\section{CRA Disclosures}

The CRA data on small business, small farm, and community development lending are made available to the public via the financial institutions covered by the act, central data depositories (usually a public library, regional planning agency, or other public entity), and the FFIEC. Under the regulation, each financial institution submits its lending data to the Federal Reserve Board, which processes the information on behalf of the FFIEC.

From the reported information, the FFIEC prepares a disclosure statement for each institution and an aggregate report for each MSA and nonmetropolitan county in the United States and Puerto Rico. The aggregate reports display lending activity by census tract. To better protect the confidentiality of the business relationships underlying the data, disclosure statements for individual lenders group and display the lending information in a limited number of income categories. For lending activity in counties that have 500,000 or fewer residents, the data are shown in four income categories-low, moderate, middle, and upper (see the box "Categorization of Neighborhoods by Relative Median Family Income"). For larger counties, the data are displayed in income categories arrayed in intervals of 10 percentage points up to a final group, 120 percent or more of the median family income for the county.

Individual institutions make their disclosure statements available at their home office. Organizations with offices in more than one state must make the statements available at one office in each of those states. Central depositories throughout the nation have the aggregate disclosure statements for inspection by the public. In addition, the FFIEC provides disclosure statements and aggregate reports in paper form and on CD-ROM. A single CD-ROM contains all of the 1996 CRA data together with an audio-visual tutorial to help users access, view, and print disclosure statements of individual institutions and aggregate statements. The CD-ROM also includes a comprehensive online help system and a function that allows users to copy the CRA data for use in other applications software. The FFIEC believes that public access to the CRA data will be greatly enhanced by electronic disclosure and that the costs associated with distribution of the data will be substantially lowered by reducing the traditional reliance on paper copies.

The CRA data order form, which may be used to order the CD-ROM for $\$ 10$, and the location of each central depository for an MSA are available on the FFIEC's Internet site at http://www.ffiec.gov. The order form may also be obtained by calling the CRA Assistance Line at (202) 872-7584. A copy of the September 30, 1997, press release announcing the availability of the new CRA data is available from the Federal Reserve Board's Publications Section at (202) 452-3245 and on the FFIEC's Web site.
For post office box addresses, loans were coded by the lender according to the census tract of the post office rather than the census tract location of the business. ${ }^{11}$ This procedure creates two potential problems. First, the characteristics of the census tract where the post office is located may be different from those of the census tract where the firm is located. ${ }^{12}$ Second, the data may show inordinately high numbers of loans in some census tracts with post offices because many businesses or farms outside the census tract containing the post office may use that office's boxes to receive correspondence.

The extent of difficulties created by coding based on post office boxes is unclear. However, because a firm is likely to select a convenient post office to receive correspondence, it is reasonably likely that, in

11. In some cases, the census tract reported for a post office location was determined from the ZIP code of the post office by mapping the post office location to the census tract at the center of the ZIP code area.

12. For the future, the agencies have attempted to minimize the use of post office addresses when coding by clarifying the instructions to reporting institutions. The instructions emphasize that, except in unusual circumstances, the street address of the business or farm, not a post office, should be the basis for coding. most circumstances, the firm and the post office will be in close proximity. In many cases, the census tract applicable to the firm may be the same one applicable to the post office.

To better understand the possible influence of the reporting of post office box locations on the lending data, information was obtained on the census tract locations of those post offices that offer post office boxes. ${ }^{13}$ These post office box census tracts were then matched to the data on the census tract locations of small business and small farm lending reported by CRA-covered institutions.

The matching revealed that of the roughly 60,000 census tracts nationwide for which small business loans were reported, 31 percent contained a postal service office with post boxes (table 1). Of the roughly 17,000 census tracts for which small farm loans were reported, 58 percent contained an office with post box services.

13. Information on the census tract numbers of postal service locations with post office boxes was obtained from CENTRAX Services, Dallas, Texas. Census tract numbers were determined from the street addresses of post offices offering post office boxes. 
1. Post office box locations and small loans to businesses and farms, 1996

\begin{tabular}{|c|c|c|c|c|}
\hline \multirow{2}{*}{ Census tracts and lending } & \multicolumn{2}{|c|}{ Business } & \multicolumn{2}{|c|}{ Farm } \\
\hline & Number & Percent & Number & Percent \\
\hline Census tracts in all areas . & 62,186 & 100 & 62,186 & 100 \\
\hline $\begin{array}{l}\text { Census tracts with loans } \\
\text { Census tracts with }\end{array}$ & 59,631 & 95.9 & 16,959 & 27.3 \\
\hline $\begin{array}{l}\text { loans and } \\
\text { P.O. boxes ...... }\end{array}$ & 18,644 & & 9,755 & \\
\hline $\begin{array}{l}\text { As a share of } \\
\text { all tracts } \\
\text { with loans }\end{array}$ & & 31.3 & & 57.5 \\
\hline $\begin{array}{l}\text { Мемо: Number of loans } \\
\text { in census tracts }\end{array}$ & & & & \\
\hline $\begin{array}{l}\text { With P.O. boxes .......... } \\
\text { As a share of each }\end{array}$ & 876,978 & & 175,927 & $\cdots$ \\
\hline loan type ........ & $\cdots$ & 36.3 & $\cdots$ & 81.2 \\
\hline Average & & & & \\
\hline Without P.O. boxes & 37.5 & & 5.6 & $\cdots$ \\
\hline With P.O. boxes & 47.0 & & 18.0 & \\
\hline
\end{tabular}

Source. FFIEC and CENTRAX Services.

The matched data file indicated that census tracts with post office box locations received, on average, forty-seven small business loans, nearly ten more than the average census tract without post office boxes. At the same time, the typical census tract with a post office box location had virtually the same number of businesses on average as census tracts with no post office box locations-139 and 136 respectively (data not shown in table). This result suggests that some fraction of businesses use post offices outside their census tracts as their primary mailing address and that this may affect the loan distributions observed in the data. ${ }^{14}$

Differences in lending between census tracts with and without a post office box location are more significant for farm lending. Census tracts with post office boxes received, on average, eighteen small farm loans while those without a post office box location had only six. Further, of the 100 census tracts with the largest numbers of small farm loans, all but 2 included a post office that offered post office box services. On balance, the analysis suggests that, particularly for small farm lending, coding loan location by using the post office box location may influence the interpretation of the data related to the geographic distribution of loans.

\section{Timeliness of Census Data}

The 1997 CRA disclosure statements portray 1996 small business and small farm lending by census tract

14. An alternative explanation for this pattern is that businesses located in census tracts with post office box locations have a greater borrowing propensity than businesses located elsewhere. We lack data to assess this hypothesis. and census tract income grouping. Census tract boundaries and associated sociodemographic information are based on the 1990 decennial census, which is the most recent information available about the characteristics of these geographic areas. The population characteristics of some census tracts may have changed substantially since the 1990 census and the income categorization for any given census tract may no longer be the most appropriate. The supervisory agencies recognize this limitation, and examiners consider additional information that may help them better assess current conditions in a lender's CRA service area.

\section{Contextual Framework}

The most significant challenge facing those using the new CRA data will be to place the information in the proper context. Variations in demand for credit among small businesses and farms across localities as well as differences in underwriting standards and in the credit quality of local firms will greatly influence the level and distribution of lending. Analysts must consider these issues in interpreting patterns in the data.

\section{Measurement of Demand}

Nationwide there are more than 22 million businesses, most of which are small businesses or small farms. They vary considerably with respect to many characteristics, including age, location, industry, product markets, and financial condition. ${ }^{15}$ This diversity, along with differences in local economic conditions, means that the demand for small business and small farm lending will vary greatly across neighborhoods and regions. Although the new CRA data provide information on extensions of credit, they do not provide any indication of these local credit demands. Therefore, conclusions drawn from analyses using only the loan data should be made with caution, as differences in local loan volumes may reflect differences in local demands, among other things. Indeed, CRA performance assessments by the supervising agencies focus on evaluating the volume and distribution of lending in the context of local

15. See "Report to the Congress on the Availability of Credit to Small Businesses," Board of Governors of the Federal Reserve System (October 1997). 
credit needs and the capabilities and capacities of the lending institutions. For instance, examiners will consider the size and characteristics of the population in a lender's community, the number and types of small businesses and small farms, and many other factors.

\section{Supply Effects}

The volume of local lending will also reflect the influence of a number of supply-related factors, including the underwriting standards applied in a given community, the credit quality of local businesses and farms, and the expected rate of return on such lending. Variation in lending activity across communities may arise from local differences in any of these factors. For example, in areas with weak economic conditions, as often happens during regional recessions, local firms may have more uncertain prospects and hence pose more credit risks. Lenders may respond by limiting the amount and terms of credit they are willing to offer in such communities.

\section{Data Features}

In many ways, the new CRA data are quite similar to the type of data available under the original provisions of HMDA. Each institution's lending activity is aggregated at the census tract level and pertains only to originations and purchases. Further, no information is available about the characteristics of individual borrowers. While these features limit the uses of the CRA data, much as they did the original HMDA data, the new data still provide important insights into the nature and distribution of lending in local markets.

Also, the CRA data include information only about new originations and purchases of loans during 1996. The data contain no information about the total amount of small business and small farm credit outstanding or about the duration or other terms of originated or purchased loans. Therefore, conclusions drawn about an institution's lending presence in a community that rely exclusively on the CRA data may be misleading. For example, two institutions that extend comparable lending services to a community may have very different patterns of loan originations over a year depending on loan terms and products offered.

The following sections describe in some detail the 1996 CRA data. To help place this lending activity in context, we provide information on population and the number of businesses and farms in different geographic areas when possible.

\section{OVERVIEW OF THE 1996 CRA DATA}

Because the 1996 CRA data have been available for review for only a short time, relatively little is known about what the new data may reveal after thorough analysis. Also, because there are no data from previous years with which to make comparisons, time trend analysis using the 1996 data is not possible.

The focus of the present analysis is on nationwide totals rather than on the activity of any individual institution. When appropriate, comparisons are made with data on small business and small farm lending from the Report of Condition and Income (Call Report) submitted by commercial banks and some savings associations and the Thrift Financial Report submitted by savings and loan associations. In reviewing the nationwide totals, it should be noted that the lending activity of individual institutions may vary greatly, both in comparison with other institutions and with patterns for the nation as a whole, depending on their location, the types of businesses they serve, the types of products they offer, the credit standards they employ, and the nature of their local competition.

\section{The Lending Institutions}

For 1996, 2,078 institutions, consisting of 1,564 commercial banks and 514 savings associations, reported data under CRA requirements (table 2, memo item). ${ }^{16}$ Roughly 9 percent of the reporting institutions did not extend any small business or small farm loans; 44 percent did not report any community development lending (derived from table 10, memo item). Overall, 133 institutions (6 percent) extended no small business, small farm, or community development loans and reported only the census tracts or block number areas that constituted each of their CRA assessment areas. Most of the reporting institutions (75 percent) had assets of less than $\$ 1$ billion (table 2, memo item). About one-third of the com-

16. The count of commercial banks and savings associations presented here differs somewhat from the totals provided in the FFIEC's September 30, 1997, press release because, as a result of a different grouping procedure used for the press release, some savings associations were placed in the commercial bank category. 
2. Originations and purchases of small loans to businesses and farms, grouped by type of borrower and loan and distributed by type and size of lending institution, 1996

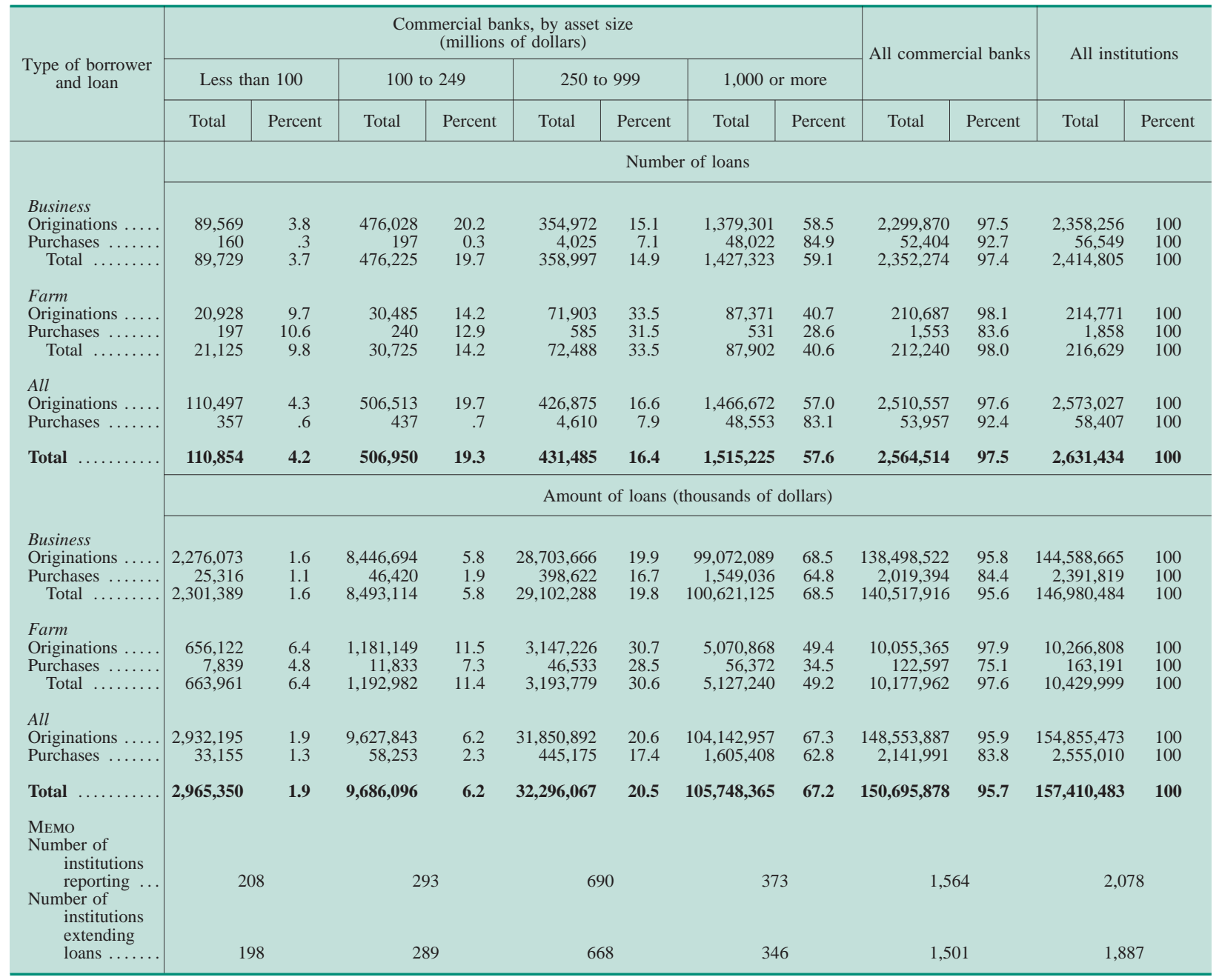

mercial banks but few of the savings associations (5 percent) had assets of less than $\$ 250$ million.

A total of 2,414,805 small business loans, for $\$ 147$ billion, and 216,629 small farm loans, totaling $\$ 10$ billion, were reported for 1996 . Unlike the case for mortgage lending, a well-developed secondary market for small business loans does not exist, and the new CRA data reflect this market reality. ${ }^{17}$ Most of the small business and small farm loans reported were originations; only about 2 percent of small business loans and less than 1 percent of small farm loans were reported as purchases from another institution.

17. The one exception is for small business loans guaranteed by the Small Business Administration. See "Report to the Congress on Markets for Small Business- and Commercial Mortgage-Related Securities," Board of Governors of the Federal Reserve System and the U.S. Securities and Exchange Commission (September 1996).
The vast majority of the reported small business loans (about 97 percent measured by the number of loans) were either originated or purchased by commercial banks or their affiliates. The large role of commercial banks relative to savings associations in small business lending is consistent with information from other data sources, including the 1987 and 1993 National Survey of Small Business Finances, which show that commercial banks are the predominant source of credit for small businesses. ${ }^{18}$ The CRA data indicate that affiliates of commercial banks and savings associations account for only a small proportion (1.1 percent) of the reported loans (table 3 ).

18. See Rebel A. Cole, John D. Wolken, and R. Louise Woodburn, "Bank and Nonbank Competition for Small Business Credit: Evidence from the 1987 and 1993 National Surveys of Small Business Finances," Federal Reserve Bulletin, vol. 82 (November 1996), pp. 983-95. 


\section{2.-Continued}

\begin{tabular}{|c|c|c|c|c|c|c|c|c|c|c|c|c|}
\hline \multirow{3}{*}{$\begin{array}{l}\text { Type of borrower } \\
\text { and loan }\end{array}$} & \multicolumn{8}{|c|}{$\begin{array}{l}\text { Savings associations, by asset size } \\
\text { (millions of dollars) }\end{array}$} & \multirow{2}{*}{\multicolumn{2}{|c|}{$\begin{array}{l}\text { All savings } \\
\text { associations }\end{array}$}} & \multirow{2}{*}{\multicolumn{2}{|c|}{ All institutions }} \\
\hline & \multicolumn{2}{|c|}{ Under 100} & \multicolumn{2}{|c|}{100 to 249} & \multicolumn{2}{|c|}{250 to 999} & \multicolumn{2}{|c|}{1,000 or more } & & & & \\
\hline & Total & Percent & Total & Percent & Total & Percent & Total & Percent & Total & Percent & Total & Percent \\
\hline & \multicolumn{12}{|c|}{ Number of loans } \\
\hline $\begin{array}{l}\text { Business } \\
\text { Originations .. } \\
\text { Purchases .... } \\
\quad \text { Total ..... }\end{array}$ & $\begin{array}{r}635 \\
4 \\
639\end{array}$ & $\begin{array}{l}* \\
* \\
*\end{array}$ & $\begin{array}{r}597 \\
0 \\
597\end{array}$ & $\begin{array}{l}* \\
* \\
*\end{array}$ & $\begin{array}{r}26,638 \\
1,391 \\
28,029\end{array}$ & $\begin{array}{l}1.1 \\
2.5 \\
1.2\end{array}$ & $\begin{array}{r}30,516 \\
2,750 \\
33,266\end{array}$ & $\begin{array}{l}1.3 \\
4.9 \\
1.4\end{array}$ & $\begin{array}{r}58,386 \\
4,145 \\
62,531\end{array}$ & $\begin{array}{l}2.5 \\
7.3 \\
2.6\end{array}$ & $\begin{array}{r}2,358,256 \\
56,549 \\
2,414,805\end{array}$ & $\begin{array}{l}100 \\
100 \\
100\end{array}$ \\
\hline $\begin{array}{l}\text { Farm } \\
\text { Originations .... } \\
\text { Purchases } . . . . \\
\quad \text { Total } \ldots \ldots \\
\quad\end{array}$ & $\begin{array}{r}81 \\
0 \\
81\end{array}$ & $\begin{array}{l}* \\
.0 \\
*\end{array}$ & $\begin{array}{r}124 \\
0 \\
124\end{array}$ & $\begin{array}{l}.1 \\
.0 \\
.1\end{array}$ & $\begin{array}{r}1,789 \\
80 \\
1,869\end{array}$ & $\begin{array}{r}.8 \\
4.3 \\
.9\end{array}$ & $\begin{array}{r}2,090 \\
225 \\
2,315\end{array}$ & $\begin{array}{r}1.0 \\
12.1 \\
1.1\end{array}$ & $\begin{array}{r}4,084 \\
305 \\
4,389\end{array}$ & $\begin{array}{r}1.9 \\
16.4 \\
2.0\end{array}$ & $\begin{array}{r}214,771 \\
1,858 \\
216,629\end{array}$ & $\begin{array}{l}100 \\
100 \\
100\end{array}$ \\
\hline $\begin{array}{l}\text { All } \\
\text { Originations .. } \\
\text { Purchases .... }\end{array}$ & $\begin{array}{r}716 \\
4\end{array}$ & * & $\begin{array}{r}721 \\
0\end{array}$ & 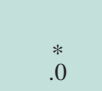 & $\begin{array}{r}28,427 \\
1,417\end{array}$ & $\begin{array}{l}1.1 \\
2.5\end{array}$ & $\begin{array}{r}32,606 \\
2,975\end{array}$ & $\begin{array}{l}1.3 \\
5.1\end{array}$ & $\begin{array}{r}62,470 \\
4,450\end{array}$ & $\begin{array}{l}2.4 \\
7.6\end{array}$ & $\begin{array}{r}2,573,027 \\
58,407\end{array}$ & $\begin{array}{l}100 \\
100\end{array}$ \\
\hline \multirow[t]{2}{*}{ Total } & 720 & * & 721 & * & 29,898 & 1.1 & 35,581 & 1.4 & 66,920 & 2.5 & $2,631,434$ & 100 \\
\hline & \multicolumn{12}{|c|}{ Amount of loans (thousands of dollars) } \\
\hline $\begin{array}{l}\text { Business } \\
\text { Originations . } \\
\text { Purchases ... } \\
\quad \text { Total .... }\end{array}$ & $\begin{array}{r}63,787 \\
2,119 \\
65,906\end{array}$ & $\begin{array}{l}* \\
* \\
*\end{array}$ & $\begin{array}{r}61,718 \\
0 \\
61,718\end{array}$ & $\begin{array}{l}* \\
.0 \\
*\end{array}$ & $\begin{array}{r}2,796,333 \\
157,720 \\
2,954,053\end{array}$ & $\begin{array}{l}1.9 \\
6.6 \\
2.0\end{array}$ & $\begin{array}{r}3,168,305 \\
212,586 \\
3,380,891\end{array}$ & $\begin{array}{l}2.2 \\
8.9 \\
2.3\end{array}$ & $\begin{array}{r}6,090,143 \\
372,425 \\
6,462,568\end{array}$ & $\begin{array}{r}4.2 \\
15.6 \\
4.4\end{array}$ & $\begin{array}{r}144,588,665 \\
2,391,819 \\
146,980,484\end{array}$ & $\begin{array}{l}100 \\
100 \\
100\end{array}$ \\
\hline $\begin{array}{l}\text { Farm } \\
\text { Originations . } \\
\text { Purchases .... } \\
\text { Total ..... }\end{array}$ & $\begin{array}{r}4,294 \\
0 \\
4,294\end{array}$ & $\begin{array}{l}* \\
.0 \\
*\end{array}$ & $\begin{array}{r}8,289 \\
0 \\
8,289\end{array}$ & $\begin{array}{l}.1 \\
.0 \\
.1\end{array}$ & $\begin{array}{r}84,850 \\
7,066 \\
91,916\end{array}$ & $\begin{array}{r}.8 \\
4.3 \\
.9\end{array}$ & $\begin{array}{r}114,010 \\
33,528 \\
147,538\end{array}$ & $\begin{array}{r}1.1 \\
20.5 \\
1.4\end{array}$ & $\begin{array}{r}211,443 \\
40,594 \\
252,037\end{array}$ & $\begin{array}{r}4.1 \\
16.2 \\
2.4\end{array}$ & $\begin{array}{r}10,266,808 \\
163,191 \\
10,429,999\end{array}$ & $\begin{array}{l}100 \\
100 \\
100\end{array}$ \\
\hline $\begin{array}{l}\text { All } \\
\text { Originations ..... } \\
\text { Purchases ...... }\end{array}$ & $\begin{array}{r}68,081 \\
2,119\end{array}$ & * & $\begin{array}{r}70,007 \\
0\end{array}$ & $\stackrel{*}{.0}$ & $\begin{array}{r}2,881,183 \\
164,786\end{array}$ & $\begin{array}{l}1.9 \\
6.4\end{array}$ & $\begin{array}{r}3,282,315 \\
246,114\end{array}$ & $\begin{array}{l}2.1 \\
9.6\end{array}$ & $\begin{array}{r}6,301,586 \\
413,019\end{array}$ & $\begin{array}{r}2.4 \\
13.4\end{array}$ & $\begin{array}{r}154,855,473 \\
2,555,010\end{array}$ & $\begin{array}{l}100 \\
100\end{array}$ \\
\hline 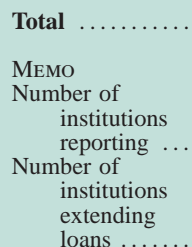 & \multicolumn{2}{|c|}{9} & \multicolumn{2}{|c|}{16} & \multicolumn{2}{|c|}{346} & \multicolumn{2}{|c|}{143} & \multicolumn{2}{|c|}{514} & \multicolumn{2}{|c|}{2,078} \\
\hline
\end{tabular}

NotE. In this and subsequent tables, percentages may not sum to 100 because of rounding. Institutions reporting are independent institutions with total assets of $\$ 250$ million or more and institutions of any size if owned by a holding company that has assets of $\$ 1$ billion or more. Savings associations

consist of savings banks and savings and loan associations. The maximum size of loan reported is $\$ 1$ million for businesses and $\$ 500,000$ for farms. * Less than 0.05 percent. SOURCE. FFIEC.

\section{Concentration of Lending Activity}

Although a minority in number, larger commercial banks and savings associations (those with assets of $\$ 1$ billion or more) originated or purchased the majority (60.5 percent) of the reported small business loans. No significant differences between commercial banks and savings associations were observed in this regard, as larger institutions did the majority of small business lending within each institutional category. For small farm loans the overall pattern is less striking, as larger institutions accounted for 42 percent.

As suggested, wide variation exists across institutions in the number and dollar amount of their reported lending. A ranking of reporting institutions by type of loan-first by number of loans and then by dollar amount-further illustrates this variation (table 4). ${ }^{19}$ A ranking of reporters by number of loans shows that the top 1 percent of the lenders originated or purchased 46 percent of the small business loans, 13 percent of the small farm loans, and 26 percent of the community development loans. When the dollar amount of lending is considered using this ranking scheme, however, the distributions are less skewed. For example, while the top 1 percent of the reporters extended 46 percent of the number of small business loans, these institutions extended only 18.6 percent of

19. For ranking purposes, small business loans, small farm loans, and community development lending were each ranked separately. 
3. Small loans to firms by affiliated lenders, as a share of all small loans to businesses and farms by commercial banks and savings associations, 1996

\begin{tabular}{|c|c|c|c|c|c|c|}
\hline \multirow[b]{2}{*}{ Type of borrower } & \multicolumn{2}{|c|}{ Lending by commercial bank affiliates } & \multicolumn{2}{|c|}{ Lending by savings association affiliates } & \multicolumn{2}{|c|}{ Lending by all affiliates } \\
\hline & Total & $\begin{array}{l}\text { Share of } \\
\text { commercial } \\
\text { bank loans }\end{array}$ & Total & $\begin{array}{l}\text { Share of savings } \\
\text { association loans }\end{array}$ & Total & Share of all loans \\
\hline & \multicolumn{6}{|c|}{ Number of loans } \\
\hline $\begin{array}{l}\text { Business } \ldots \ldots \ldots \ldots \ldots \ldots \ldots \ldots \\
\text { Farm } \ldots \ldots \ldots \ldots \ldots \ldots \ldots \ldots \ldots \\
\text { All } \ldots \ldots \ldots \ldots \ldots \ldots \ldots\end{array}$ & $\begin{array}{r}27,533 \\
624 \\
28,157\end{array}$ & $\begin{array}{r}1.2 \\
.3 \\
1.1\end{array}$ & $\begin{array}{r}835 \\
14 \\
849\end{array}$ & $\begin{array}{r}1.3 \\
.3 \\
1.3\end{array}$ & $\begin{array}{r}28,368 \\
638 \\
29,006\end{array}$ & $\begin{array}{r}1.2 \\
.3 \\
1.1\end{array}$ \\
\hline All $\ldots \ldots \ldots \ldots \ldots \ldots \ldots \ldots$ & \multicolumn{6}{|c|}{ Amount of loans (thousands of dollars) } \\
\hline $\begin{array}{l}\text { Business } \ldots \ldots \ldots \ldots \ldots \ldots \ldots \ldots \ldots \ldots \ldots \ldots \\
\text { Farm } \ldots \ldots \ldots \ldots \ldots \ldots \ldots \ldots \ldots \ldots \\
\text { All } \ldots \ldots \ldots \ldots \ldots \ldots \ldots \ldots\end{array}$ & $\begin{array}{r}1,046,673 \\
52,063 \\
1,098,736\end{array}$ & $\begin{array}{l}.7 \\
.5 \\
.7\end{array}$ & $\begin{array}{r}128,753 \\
105 \\
128,858\end{array}$ & $\begin{array}{c}2.0 \\
* \\
1.9\end{array}$ & $\begin{array}{r}1,175,426 \\
52,168 \\
1,227,594\end{array}$ & $\begin{array}{l}.8 \\
.5 \\
.8\end{array}$ \\
\hline $\begin{array}{l}\text { Мемо } \\
\text { Number of institutions } \\
\quad \text { extending loans .... }\end{array}$ & \multicolumn{2}{|c|}{118} & & & \multicolumn{2}{|c|}{127} \\
\hline
\end{tabular}

* Less than 0.05 percent.

the small business loan dollars. In other words, the average small business loan extended by these active lenders was relatively small.

The highly concentrated nature of the reported lending that is apparent when institutions are ranked by number of loans also holds when institutions are ranked by the dollar amount of their lending (table 4). By this ranking, the top 1 percent of lenders extended 22 percent of small business loan dollars, 17 percent of small farm loan dollars, and 32 percent of community development loan dollars.

\section{Specialized Banks}

The CRA data include lending information from institutions that differ considerably in their product offerings and market specializations. Although most

4. Small loans to businesses and farms and loans for community development, grouped by type of loan and distributed by institution ranked by amount of lending, 1996

Percent

\begin{tabular}{|c|c|c|c|c|c|c|}
\hline \multirow{2}{*}{$\begin{array}{l}\text { Institutions by } \\
\text { amount of lending } \\
\text { (percent) }\end{array}$} & \multicolumn{2}{|c|}{ Business loans ${ }^{1}$} & \multicolumn{2}{|c|}{ Farm loans ${ }^{1}$} & \multicolumn{2}{|c|}{$\begin{array}{c}\text { Community } \\
\text { development loans }{ }^{1}\end{array}$} \\
\hline & By number & By dollars & By number & By dollars & By number & By dollars \\
\hline \multicolumn{7}{|l|}{$\begin{array}{l}\text { Institutions ranked } \\
\text { by number of loans }\end{array}$} \\
\hline Top $1 \ldots \ldots \ldots \ldots$. & 46.1 & 18.6 & 13.3 & 13.6 & 26.0 & 7.8 \\
\hline $2-5 \ldots \ldots \ldots \ldots \ldots$ & 18.6 & 28.2 & 26.1 & 26.2 & 27.3 & 36.7 \\
\hline $6-9$. & 9.6 & 14.5 & 17.8 & 17.1 & 11.9 & 14.5 \\
\hline $10-19$ & 9.2 & 13.5 & 19.7 & 20.2 & 13.4 & 14.8 \\
\hline $20-49$ & 11.8 & 17.8 & 20.03 & 19.1 & 15.8 & 20.3 \\
\hline $50-74$ & 3.7 & 5.5 & 2.7 & 3.1 & 4.3 & 4.5 \\
\hline $75-100 \ldots \ldots$ & .9 & 1.8 & .4 & .7 & 1.4 & 1.3 \\
\hline All $\ldots \ldots \ldots \ldots \ldots \ldots \ldots \ldots \ldots \ldots$ & 100 & 100 & 100 & 100 & 100 & 100 \\
\hline \multicolumn{7}{|l|}{$\begin{array}{l}\text { Institutions ranked } \\
\text { by dollar amount of loans }\end{array}$} \\
\hline Top $1 \ldots \ldots \ldots \ldots \ldots$ & 30.7 & 21.8 & 11.7 & 17.4 & 8.6 & 31.9 \\
\hline $2-5 \ldots \ldots \ldots \ldots \ldots \ldots$ & 31.1 & 27.6 & 24.4 & 26.5 & 23.3 & 29.7 \\
\hline $6-9$ & 10.5 & 14.3 & 17.7 & 18.2 & 17.5 & 14.1 \\
\hline $10-19$ & 8.9 & 13.7 & 20.1 & 18.0 & 18.6 & 12.7 \\
\hline $20-49$ & 13.0 & 16.6 & 21.9 & 16.9 & 21.2 & 9.8 \\
\hline $50-74$. & 4.5 & 4.8 & 3.5 & 2.6 & 7.5 & 1.5 \\
\hline $75-100$ & 1.3 & 1.2 & .7 & .4 & 3.4 & 3 \\
\hline All..... & 100 & 100 & 100 & 100 & 100 & 100 \\
\hline \multicolumn{7}{|l|}{ Мемо } \\
\hline Number of loans ...... & $2,414,805$ & & 216,629 & & 32,677 & \\
\hline Amount (in thousands) $\ldots \ldots$. & & $146,980,484$ & & $10,429,999$ & & $17,708,161$ \\
\hline Number of lenders with data ${ }^{2} \ldots \ldots \ldots$ & 1,886 & $\ldots$ & 1,150 & $\ldots$ & 1,156 & $\ldots$ \\
\hline
\end{tabular}


of the CRA reporters offer a wide range of products, some do not. Among these "specialized" banks, the group most involved in small business lending are those institutions that specialize in credit card lending (referred to as credit card banks). In total, the CRA data include information from thirty-nine credit card banks, of which twelve reported some amount of small business lending in 1996. These twelve credit card banks accounted for a substantial proportion of all the small business lending reported by CRAcovered institutions when measured by number of loans, but a much smaller proportion when measured in dollars. In 1996, credit card banks accounted for 30 percent of the number of reported small business loans but only 2.9 percent of the dollar amount of such loans. ${ }^{20}$ Although credit card banks reporting CRA data were relatively active small business lenders, they did little small farm lending: In 1996, they extended fewer than 100 small farm loans.

\section{Size of Loans and Size of Borrowers}

The new CRA data include information about the size of small business and small farm loans. For 1996, the average small business loan was about $\$ 61,000$ and the average small farm loan was about $\$ 48,000$ at institutions reporting under CRA, and 87 percent of the small business loans and 88 percent of the small farm loans (measured by number of loans) were for $\$ 100,000$ or less (table 5). Measured by dollar volume, the distribution differs: 29 percent of small business loan dollars and 44 percent of small farm loan dollars were for $\$ 100,000$ or less.

The new CRA data also provide information on how many of the reported loans were extended to businesses or farms with revenues of $\$ 1$ million or less. For 1996, 56 percent of the reported small business loans and 88 percent of the small farm loans (measured by number of loans) were extended to firms and farms with revenues of $\$ 1$ million or less (table 5). ${ }^{21}$ The data show that, on average, loans to small businesses with revenues of $\$ 1$ million or less are smaller than those to larger firms. For example,

20. The CRA regulations direct institutions that issue credit cards to the employees of a small business to report all of the credit card lines opened on a particular day as a single business loan with the "amount of the loan" equivalent to the sum of the available credit lines of those credit card accounts opened on that day.

21. Patterns among credit card banks are quite similar-51 percent of their small business loans were extended to firms with revenues of $\$ 1$ million or less. the average loan to these small businesses was about $\$ 46,000$, while the average loan amount for larger firms was $\$ 79,000$ (derived from table 5). Similarly, the average size of the loan to farms with revenues of $\$ 1$ million or less was about $\$ 44,000$, and that to larger farms was about $\$ 77,000$.

\section{How Comprehensive Are the CRA Data?}

As of December 31, 1996, there were 9,446 insured commercial banks and 1,980 savings associations. ${ }^{22}$ The new CRA data on small business and small farm lending include the lending activity of only the largest commercial banks and savings associations, which represent just 18 percent of all commercial banks and savings associations.

To assess the extent that the CRA covers small business and small farm lending activity, a comparison was made between the small business and small farm lending activity of CRA-covered institutions and that of all commercial banks and savings associations as reported on the Call Report and the Thrift Financial Report. ${ }^{23}$ Call Reports and Thrift Financial Reports include the outstanding amount of small loans to businesses and farms for all commercial banks and savings associations. This analysis thus compares the outstanding amounts for CRA reporters with the outstanding amounts for all commercial banks and savings associations as of June 1996.

The comparison shows that the CRA reporters accounted for 64.6 percent of the number of small business loans and 65.9 percent of the dollar amount of such loans outstanding in June 1996. Similarly, the CRA reporters extended 21.6 percent of the number of small farm loans and 27.5 percent of the dollar amount of such loans. Thus, despite the limited institutional coverage of the CRA data reporting requirements, CRA reporters accounted for a sizable fraction of the small business loans reported by all commercial banks and savings associations. However, they accounted for a much smaller fraction of small farm lending.

22. See "Financial Structure Information," Financial Structure Section, Division of Research and Statistics, Board of Governors of the Federal Reserve System, March 25, 1997. Savings associations included in the structure data are state-chartered savings banks, federal savings banks, savings and loan associations, industrial banks, and cooperative banks.

23. We use the Call Report and Thrift Financial Report because they include comparable data regarding both CRA reporters and institutions not required to report under the CRA. 
5. Originations and purchases of small loans to businesses and farms, by size of loan, 1996

\begin{tabular}{|c|c|c|c|c|c|c|c|c|c|c|}
\hline \multirow{3}{*}{$\begin{array}{l}\text { Type of borrower } \\
\text { and loan }\end{array}$} & \multicolumn{6}{|c|}{ Size of loan (dollars) } & \multirow{2}{*}{\multicolumn{2}{|c|}{ All loans }} & \multirow{2}{*}{\multicolumn{2}{|c|}{$\begin{array}{c}\text { Mемо } \\
\text { Loans to firms } \\
\text { with revenues } \\
\text { of } \$ 1 \text { million } \\
\text { or less }\end{array}$}} \\
\hline & \multicolumn{2}{|c|}{100,000 or less } & \multicolumn{2}{|c|}{100,001 to 250,000} & \multicolumn{2}{|c|}{ More than 250,000} & & & & \\
\hline & Total & Percent & Total & Percent & Total & Percent & Total & Percent & Total & Percent \\
\hline & \multicolumn{10}{|c|}{ Number of loans } \\
\hline $\begin{array}{l}\text { Business } \\
\text { Originations ... } \\
\text { Purchases .... } \\
\quad \text { Total ...... }\end{array}$ & $\begin{array}{r}2,046,056 \\
52,660 \\
2,098,716\end{array}$ & $\begin{array}{l}86.8 \\
93.1 \\
86.9\end{array}$ & $\begin{array}{r}171,712 \\
1,901 \\
173,613\end{array}$ & $\begin{array}{l}7.3 \\
3.4 \\
7.2\end{array}$ & $\begin{array}{r}140,488 \\
1,988 \\
142,476\end{array}$ & $\begin{array}{l}6.0 \\
3.5 \\
5.9\end{array}$ & $\begin{array}{r}2,358,256 \\
56,549 \\
2,414,805\end{array}$ & $\begin{array}{l}100 \\
100 \\
100\end{array}$ & $\begin{array}{l}\text { n.a. } \\
\text { n.a. } \\
1,349,824\end{array}$ & $\begin{array}{l}\text { n.a. } \\
\text { n.a. } \\
55.9\end{array}$ \\
\hline $\begin{array}{l}\text { Farm } \\
\text { Originations ... } \\
\text { Purchases .... } \\
\quad \text { Total ...... }\end{array}$ & $\begin{array}{r}188,252 \\
1,367 \\
189,619\end{array}$ & $\begin{array}{l}87.7 \\
73.6 \\
87.5\end{array}$ & $\begin{array}{r}19,604 \\
334 \\
19,938\end{array}$ & $\begin{array}{r}9.1 \\
18.0 \\
9.2\end{array}$ & $\begin{array}{r}6,915 \\
157 \\
7,072\end{array}$ & $\begin{array}{l}3.2 \\
8.4 \\
3.3\end{array}$ & $\begin{array}{r}214,771 \\
1,858 \\
216,629\end{array}$ & $\begin{array}{l}100 \\
100 \\
100\end{array}$ & $\begin{array}{l}\text { n.a. } \\
\text { n.a. } \\
191,027\end{array}$ & $\begin{array}{l}\text { n.a. } \\
\text { n.a. } \\
88.2\end{array}$ \\
\hline $\begin{array}{l}\text { All } \\
\text { Originations ..... } \\
\text { Purchases ..... }\end{array}$ & $\begin{array}{r}2,234,308 \\
54,027\end{array}$ & $\begin{array}{l}86.8 \\
92.5\end{array}$ & $\begin{array}{r}191,316 \\
2,235\end{array}$ & $\begin{array}{l}7.4 \\
3.8\end{array}$ & $\begin{array}{r}147,403 \\
2,145\end{array}$ & $\begin{array}{l}5.7 \\
3.7\end{array}$ & $\begin{array}{r}2,573,027 \\
58,407\end{array}$ & $\begin{array}{l}100 \\
100\end{array}$ & $\begin{array}{l}\text { n.a. } \\
\text { n.a. }\end{array}$ & $\begin{array}{l}\text { n.a. } \\
\text { n.a. }\end{array}$ \\
\hline \multirow[t]{2}{*}{ Total } & $2,288,335$ & 87.0 & 193,551 & 7.4 & 149,548 & 5.7 & $2,631,434$ & 100 & $1,540,851$ & 58.6 \\
\hline & \multicolumn{10}{|c|}{ Amount of loans (thousands of dollars) } \\
\hline $\begin{array}{l}\text { Business } \\
\text { Originations } \ldots . . . \\
\text { Purchases } \ldots \ldots \ldots \\
\quad \text { Total } \ldots \ldots \ldots .\end{array}$ & $\begin{array}{r}42,021,720 \\
1,018,717 \\
43,040,437\end{array}$ & $\begin{array}{l}29.1 \\
42.6 \\
29.3\end{array}$ & $\begin{array}{r}29,574,408 \\
308,657 \\
29,883,065\end{array}$ & $\begin{array}{l}20.5 \\
12.9 \\
20.3\end{array}$ & $\begin{array}{r}72,992,537 \\
1,064,445 \\
74,056,982\end{array}$ & $\begin{array}{l}50.5 \\
44.5 \\
50.4\end{array}$ & $\begin{array}{r}144,588,665 \\
2,391,819 \\
146,980,484\end{array}$ & $\begin{array}{l}100 \\
100 \\
100\end{array}$ & $\begin{array}{l}\text { n.a. } \\
\text { n.a. } \\
62,583,338\end{array}$ & $\begin{array}{l}\text { n.a. } \\
\text { n.a. } \\
42.6\end{array}$ \\
\hline $\begin{array}{l}\text { Farm } \\
\text { Originations } \ldots . \\
\text { Purchases } \ldots \ldots \\
\quad \text { Total } \ldots \ldots .\end{array}$ & $\begin{array}{r}4,556,028 \\
48,277 \\
4,604,305\end{array}$ & $\begin{array}{l}44.4 \\
29.6 \\
44.1\end{array}$ & $\begin{array}{r}3,208,692 \\
55,673 \\
3,264,365\end{array}$ & $\begin{array}{l}31.3 \\
34.1 \\
31.3\end{array}$ & $\begin{array}{r}2,502,088 \\
59,241 \\
2,561,329\end{array}$ & $\begin{array}{l}24.4 \\
36.3 \\
24.6\end{array}$ & $\begin{array}{r}10,266,808 \\
163,191 \\
10,429,999\end{array}$ & $\begin{array}{l}100 \\
100 \\
100\end{array}$ & $\begin{array}{l}\text { n.a. } \\
\text { n.a. } \\
8,469,677\end{array}$ & $\begin{array}{l}\text { n.a. } \\
\text { n.a. } \\
81.2\end{array}$ \\
\hline $\begin{array}{l}\text { All } \\
\text { Originations } \\
\text { Purchases ... }\end{array}$ & $\begin{array}{r}46,577,748 \\
1,066,994\end{array}$ & $\begin{array}{l}30.0 \\
41.8\end{array}$ & $\begin{array}{r}32,783,100 \\
364,330\end{array}$ & $\begin{array}{l}21.2 \\
14.3\end{array}$ & $\begin{array}{r}75,494,625 \\
1,123,686\end{array}$ & $\begin{array}{l}48.8 \\
44.0\end{array}$ & $\begin{array}{r}154,855,473 \\
2,555,010\end{array}$ & $\begin{array}{l}100 \\
100\end{array}$ & $\begin{array}{l}\text { n.a. } \\
\text { n.a. }\end{array}$ & $\begin{array}{l}\text { n.a. } \\
\text { n.a. }\end{array}$ \\
\hline Total & $47,644,742$ & 30.3 & $33,147,430$ & 21.1 & $76,618,311$ & 48.7 & $157,410,483$ & 100 & $71,053,015$ & 45.1 \\
\hline
\end{tabular}

\section{Analysis of Lending by Location and Area Income}

The availability of information about the geographic location of businesses and farms receiving credit provides an opportunity to examine regional credit flows and the distribution of small business and small farm lending across areas grouped by their sociodemographic and economic characteristics. Because the new CRA data do not include the lending of all commercial banks and savings associations, the data do not fully represent all small business and small farm lending by these types of institutions. Nonetheless, as noted, covered institutions represent a significant portion of such lending.

\section{Distribution of Lending by Census Tract}

Like the number of businesses and farms, the distribution of small business and small farm lending varies geographically. The 1996 CRA data reveal that
CRA-reporting institutions extended small business loans in the vast majority (96 percent) of census tracts nationwide (derived from table 6, memo items). Reflecting the rural location of most farm lending, the proportion of all census tracts receiving farm loans is much smaller ( 27 percent) than the proportion of census tracts receiving small business loans.

Although at least some small business loans are made in most geographic areas, small business lending by CRA-reporting institutions tends to be rather concentrated geographically. When census tracts receiving at least one loan are ranked by number of small business loans in 1996 (table 6, top panel), the top 5 percent received 26 percent of all small business loans. Ranking census tracts by the dollar amount of small business lending (bottom panel of table 6) indicates that in 1996 the top 5 percent received 33 percent of the small business loan dollars. Small farm lending is even more concentrated than small business lending; for example, the 5 percent of census tracts with the highest levels of farm lending (measured by number of loans) received 41 percent of the small farm loans. 
6. Small loans to businesses and farms, grouped by type of loan and distributed by census tract ranked by amount of lending, 1996 Percent

\begin{tabular}{|c|c|c|c|c|}
\hline \multirow{2}{*}{$\begin{array}{c}\text { Census tracts } \\
\text { by amount of lending }\end{array}$} & \multicolumn{2}{|c|}{ Business loans } & \multicolumn{2}{|c|}{ Farm loans } \\
\hline & By number & By dollars & By number & By dollars \\
\hline \multicolumn{5}{|l|}{$\begin{array}{l}\text { Census tracts ranked } \\
\text { by number of loans }\end{array}$} \\
\hline Top $1 \ldots \ldots \ldots \ldots$ & 9.3 & 11.4 & 15.5 & 12.2 \\
\hline $2-5 \ldots$ & 16.4 & 18.4 & 25.6 & 24.1 \\
\hline $6-9$. & 12.9 & 13.5 & 16.6 & 16.4 \\
\hline $10-19$ & 17.6 & 17.8 & 18.0 & 19.2 \\
\hline $20-49$ & 28.7 & 26.6 & 18.3 & 20.5 \\
\hline $50-74$ & 11.2 & 9.4 & 4.1 & 5.4 \\
\hline $75-100$ & 3.9 & 2.9 & 2.0 & 2.4 \\
\hline Total & 100 & 100 & 100 & 100 \\
\hline \multicolumn{5}{|l|}{$\begin{array}{l}\text { Census tracts ranked } \\
\text { by dollar amount of loans }\end{array}$} \\
\hline Top $1 \ldots \ldots \ldots \ldots \ldots$ & 8.3 & 13.1 & 12.1 & 15.8 \\
\hline $2-5, \ldots \ldots \ldots \ldots \ldots$ & 14.8 & 20.2 & 23.2 & 25.9 \\
\hline $6-9$. & 12.1 & 14.4 & 16.7 & 16.9 \\
\hline $10-19$ & 17.0 & 18.2 & 18.2 & 18.4 \\
\hline $20-49$ & 29.6 & 25.4 & 20.6 & 18.9 \\
\hline $50-74$ & 13.1 & 7.3 & 6.3 & 3.5 \\
\hline $75-100$ & 5.2 & 1.5 & 2.9 & 6 \\
\hline Total & 100 & 100 & 100 & 100 \\
\hline \multicolumn{5}{|l|}{ МЕмо } \\
\hline Number of loans & $2,414,805$ & $\ldots$ & 216,629 & \\
\hline $\begin{array}{l}\text { Amount of loans } \\
\text { (thousands }\end{array}$ & & & & \\
\hline $\begin{array}{l}\text { of dollars) ........... } \\
\text { Number of census tracts }\end{array}$ & & $146,980,484$ & & $10,429,999$ \\
\hline with loans .......... & 59,631 & . & 16,959 & \\
\hline $\begin{array}{l}\text { Total number } \\
\text { of census tracts ..... }\end{array}$ & 62,186 & & 62,186 & \\
\hline
\end{tabular}

NotE. Includes only census tracts with the relevant type of loan. SOURCE. FFIEC.

\section{Credit Flows by Region of the Country}

To examine regional credit flows, reported loans were grouped by census region. Small business lending varies by region of the country roughly in proportion to the distribution of businesses. For example, New England had 5 percent of the small business loans (table 7) and 5.9 percent of the businesses (table 7, memo item). The South Atlantic region had 20.4 percent of the small business loans and 17.8 percent of the businesses.

The regional variation in small farm lending is more pronounced than in small business lending. The New England region had the smallest share (less than 1 percent) of all small farm lending by CRAreporting institutions (measured either by number or dollar amount of loans) and the West North Central region had the largest share (more than 30 percent). As with small business loans, this regional variation fairly closely tracks differences in the share of farms and the share of farm revenues by region. For example, although New England had the smallest share of the small farm lending, it also had the smallest share of the nation's farms (1.3 percent) and farm revenues (1.2 percent).

\section{Categorization of Neighborhoods by Relative Household Median Income}

In counties with less than 500,000 residents, census tracts are grouped in broad categories. The categories are defined by the median household income in the census tract as a percentage of the median household income in the MSA or in the nonmetropolitan portion of the state (if the census tract is not located in an MSA). The categories are shown in the table below.

\begin{tabular}{c|c|c}
\hline $\begin{array}{c}\text { Income category } \\
\text { of census tract }\end{array}$ & $\begin{array}{c}\text { Percentage of } \\
\text { area median }\end{array}$ & $\begin{array}{c}\text { Share of census tracts } \\
\text { in 1996 (percent) }{ }^{1}\end{array}$ \\
\hline Low $\ldots \ldots \ldots \ldots \ldots \ldots$ & Less than 50 & 6.5 \\
Moderate $\ldots \ldots \ldots \ldots \ldots$ & $50-80$ & 19.2 \\
Middle $\ldots \ldots \ldots \ldots \ldots$ & $80-120$ & 50.4 \\
Upper .............. & More than 120 & 20.8 \\
\hline
\end{tabular}

1. Shares do not sum to 100 percent because median income was not reported by the Bureau of the Census for 3.1 percent of the census tracts.

\section{Credit Flows by Neighborhood Income}

CRA performance assessments include an analysis of the distribution of small business and small farm loans across census tracts grouped into four neighborhood income categories: low, moderate, middle, and upper (see the box "Categorization of Neighborhoods by Relative Median Family Income"). Concerns have been expressed that small business loans are not sufficiently available in lower-income neighborhoods, particularly those in central cities. The data suggest that, at least from a national perspective, such concerns may be overstated, as the distribution of the number and the dollar amounts of small business loans across the four income categories generally follows the distribution of population and businesses across these groups (table 8.A). For example, lowincome areas include about 4.9 percent of the population and 5.6 percent of all businesses; and they received 4.7 percent of the number and 5.6 percent of the total dollar amount of new or purchased small business loans at CRA-reporting institutions. ${ }^{24}$ Some larger differences are observed in areas with higher incomes. The total amount of lending to middle- and upper-income neighborhoods taken together only slightly exceeds their share of the population and of businesses. These lending patterns stand in marked contrast to the distribution of home purchase loans,

\footnotetext{
24. Data on population and lending activity include Puerto Rico.
} 
7. Originations and purchases of small loans to businesses and farms, by region, 1996

\begin{tabular}{|c|c|c|c|c|c|c|c|c|c|c|}
\hline \multirow{2}{*}{$\begin{array}{l}\text { Type of borrower } \\
\text { and loan }\end{array}$} & \multicolumn{2}{|c|}{ New England } & \multicolumn{2}{|c|}{ Middle Atlantic } & \multicolumn{2}{|c|}{ East North Central } & \multicolumn{2}{|c|}{ West North Central } & \multicolumn{2}{|c|}{ South Atlantic } \\
\hline & Total & Percent & Total & Percent & Total & Percent & Total & Percent & Total & Percent \\
\hline & \multicolumn{10}{|c|}{ Number of loans } \\
\hline \multicolumn{11}{|l|}{ Business } \\
\hline Originations & 117,469 & 5.0 & 322,205 & 13.7 & 366,551 & 15.5 & 180,875 & 7.7 & 476,862 & 20.2 \\
\hline Purchases .. & 4,445 & 7.9 & 9,909 & 17.5 & 4,818 & 8.5 & 2,760 & 4.9 & 15,309 & 27.1 \\
\hline Total $\ldots$ & 121,914 & 5.0 & 332,114 & 13.8 & 371,369 & 15.4 & 183,635 & 7.6 & 492,171 & 20.4 \\
\hline \multicolumn{11}{|l|}{ Farm } \\
\hline Originations $\ldots \ldots \ldots$. & 620 & .3 & 6,868 & 3.2 & 37,098 & 17.3 & 82,399 & 38.4 & 17,895 & 8.3 \\
\hline Purchases $\ldots \ldots \ldots \ldots$. & 1 & .1 & 4 & .2 & 35 & 1.9 & 1,157 & 62.3 & 37 & 2.0 \\
\hline Total .. & 621 & .3 & 6,872 & 3.2 & 37,133 & 17.1 & 83,556 & 38.6 & 17,932 & 8.3 \\
\hline \multicolumn{11}{|l|}{ All } \\
\hline Originations ..... & 118,089 & 4.6 & 329,073 & 12.8 & 403,649 & 15.7 & 263,274 & 10.2 & 494,757 & 19.2 \\
\hline Purchases ...... & 4,446 & 7.6 & 9,913 & 17.0 & 4,853 & 8.3 & 3,917 & 6.7 & 15,346 & 26.3 \\
\hline \multirow[t]{2}{*}{ Total } & 122,535 & 4.7 & 338,986 & 12.9 & 408,502 & 15.5 & 267,191 & 10.2 & 510,103 & 19.4 \\
\hline & \multicolumn{10}{|c|}{ Amount of loans (thousands of dollars) } \\
\hline \multicolumn{11}{|l|}{ Business } \\
\hline Originations .. & $7,507,367$ & 5.2 & $22,338,690$ & 15.4 & $26,628,373$ & 18.4 & $12,233,773$ & 8.5 & $26,341,624$ & 18.2 \\
\hline Purchases ... & 210,411 & 8.8 & 376,636 & 15.7 & 405,855 & 17.0 & 214,020 & 8.9 & 441,396 & 18.5 \\
\hline Total .. & $7,717,778$ & 5.3 & $22,715,326$ & 15.5 & $27,034,228$ & 18.4 & $12,447,793$ & 8.5 & $26,783,020$ & 18.2 \\
\hline \multicolumn{11}{|l|}{ Farm } \\
\hline Originations & 38,250 & .4 & 340,974 & 3.3 & $1,727,932$ & 16.8 & $3,163,081$ & 30.8 & 811,663 & 7.9 \\
\hline Purchases .. & 270 & .2 & 93 & .1 & 3,224 & 2.0 & 89,052 & 54.6 & 4,032 & 2.5 \\
\hline Total .. & 38,520 & .4 & 341,067 & 3.3 & $1,731,156$ & 16.6 & $3,252,133$ & 31.2 & 815,695 & 7.8 \\
\hline \multicolumn{11}{|l|}{ All } \\
\hline Originations & $7,545,617$ & 4.9 & $22,679,664$ & 14.6 & $28,356,305$ & 18.3 & $15,396,854$ & 9.9 & $27,153,287$ & 17.5 \\
\hline Purchases .. & 210,681 & 8.2 & 376,729 & 14.7 & 409,079 & 16.0 & 303,072 & 11.9 & 445,428 & 17.4 \\
\hline Total & $7,756,298$ & 4.9 & $23,056,393$ & 14.6 & $28,765,384$ & 18.3 & $15,699,926$ & 10.0 & $27,598,715$ & 17.5 \\
\hline \multicolumn{11}{|l|}{ Мемо } \\
\hline $\begin{array}{l}\text { Number of businesses } \\
\text { in } 1992 \text { (thousands) }\end{array}$ & \multicolumn{2}{|c|}{307.8} & \multicolumn{2}{|c|}{815.4} & \multicolumn{2}{|c|}{828.7} & \multicolumn{2}{|c|}{402.1} & \multicolumn{2}{|c|}{932.1} \\
\hline $\begin{array}{l}\text { Share of businesses } \\
\text { (percent) } \ldots \ldots \ldots \ldots\end{array}$ & \multicolumn{2}{|c|}{5.9} & \multicolumn{2}{|c|}{15.5} & \multicolumn{2}{|c|}{15.8} & \multicolumn{2}{|c|}{7.7} & 17 & \\
\hline Number of farms & & & & & & & & & & \\
\hline in 1994 (thousands) & 26 & & 95. & & 346 & & 477 & & 248 & \\
\hline Share of farms (percent) & & & 4 & & 16 & & 23 & & 12 & \\
\hline $\begin{array}{l}\text { Share of farm revenues } \\
\text { (percent) } \ldots \ldots \ldots \ldots\end{array}$ & & & 4. & & 14 & & 24 & & 12 & \\
\hline
\end{tabular}

of which low- and moderate-income neighborhoods receive a smaller relative proportion measured by number or by dollar amount. 25

For small farm loans, about three-fourths of all lending, whether measured in number of loans or in dollars, was in middle-income census tracts (table 8.B). Only a small proportion (less than 1 percent) of reported farm lending was in low-income neighborhoods, which, as noted, have only a small proportion of the U.S. population.

\section{Credit Flows by Degree of Urbanization and Neighborhood Income}

The distribution of small business lending by CRAreporting institutions across census tracts grouped by

25. Canner and Passmore, "Home Purchase Lending in LowIncome Neighborhoods." both income and degree of urbanization (central city, suburban, or rural location) generally parallels the distribution of the U.S. population and businesses (table 8.A). Small business loans are heavily concentrated in central city and suburban areas (about 80 percent of all small business loans), as are the bulk of the U.S. population and most small businesses. ${ }^{26}$ In lower-income areas, most small business loans are made in central city census tracts; in higher-income areas, suburban census tracts have the most small business loans.

The general observation that the number of loans parallels the distribution of the population may not hold for all central city areas. ${ }^{27}$ Because businesses

26. According to the 1993 National Survey of Small Business Finances, 79 percent of small businesses are located in central city and suburban areas.

27. Previous research has identified significant differences in the economic experiences of different central city neighborhoods. For 


\section{7.-Continued}

\begin{tabular}{|c|c|c|c|c|c|c|c|c|}
\hline \multirow{2}{*}{$\begin{array}{l}\text { Type of borrower } \\
\text { and loan }\end{array}$} & \multicolumn{2}{|c|}{ East South Central } & \multicolumn{2}{|c|}{ West South Central } & \multicolumn{2}{|c|}{ Mountain } & \multicolumn{2}{|c|}{ Pacific } \\
\hline & Total & Percent & Total & Percent & Total & Percent & Total & Percent \\
\hline & \multicolumn{8}{|c|}{ Number of loans } \\
\hline \multicolumn{8}{|l|}{ Business } & \\
\hline Originations & 171,995 & 7.3 & 230,560 & 9.8 & 144,250 & 6.1 & 347,489 & 14.7 \\
\hline Purchases ... & 5,759 & 10.2 & 5,477 & 9.7 & 1,230 & 2.2 & 6,842 & 12.1 \\
\hline Total .. & 177,754 & 7.4 & 236,037 & 9.8 & 145,480 & 6.0 & 354,331 & 14.7 \\
\hline \multicolumn{9}{|l|}{ Farm } \\
\hline Originations . & 19,774 & 9.2 & 20,960 & 9.8 & 17,569 & 8.2 & 11,588 & 5.4 \\
\hline Purchases ... & 32 & 1.7 & 192 & 10.3 & 67 & 3.6 & 333 & 17.9 \\
\hline Total ... & 19,806 & 9.1 & 21,152 & 9.8 & 17,636 & 8.1 & 11,921 & 5.5 \\
\hline \multicolumn{9}{|l|}{ All } \\
\hline $\begin{array}{l}\text { Originations . } \\
\text { Purchases ... }\end{array}$ & $\begin{array}{r}191,769 \\
5,791\end{array}$ & $\begin{array}{l}7.5 \\
9.9\end{array}$ & $\begin{array}{r}251,520 \\
5,669\end{array}$ & $\begin{array}{l}9.8 \\
9.7\end{array}$ & $\begin{array}{r}161,819 \\
1,297\end{array}$ & $\begin{array}{l}6.3 \\
2.2\end{array}$ & $\begin{array}{r}359,077 \\
7,175\end{array}$ & $\begin{array}{l}14.0 \\
12.3\end{array}$ \\
\hline \multirow{3}{*}{ Total } & 197,560 & 7.5 & 257,189 & 9.8 & 163,116 & 6.2 & 366.252 & 130 \\
\hline & \multirow{2}{*}{\multicolumn{8}{|c|}{ Amount of loans (thousands of dollars) }} \\
\hline & & & & & & & & \\
\hline \multicolumn{9}{|l|}{ Business } \\
\hline Originations & $9,049,045$ & 6.3 & $11,901,436$ & 8.2 & $7,833,955$ & 5.4 & $20,754,402$ & 14.4 \\
\hline Purchases .. & 102,125 & 4.3 & 198,372 & 8.3 & 66,716 & 2.8 & 376,288 & 15.7 \\
\hline Total .. & $9,151,170$ & 6.2 & $12,099,808$ & 8.2 & $7,900,671$ & 5.4 & $21,130,690$ & 14.4 \\
\hline \multicolumn{9}{|l|}{ Farm } \\
\hline Originations & 663,873 & 6.5 & 958,193 & 9.3 & $1,155,080$ & 11.3 & $1,407,762$ & 13.7 \\
\hline Purchases .. & 1,443 & .9 & 20,107 & 12.3 & 3,621 & 2.2 & 41,349 & 25.3 \\
\hline Total .. & 665,316 & 6.4 & 978,300 & 9.4 & $1,158,701$ & 11.1 & $1,449,111$ & 13.9 \\
\hline \multicolumn{9}{|l|}{ All. } \\
\hline Originations . & $9,712,918$ & 6.3 & $12,859,629$ & 8.3 & $8,989,035$ & 5.8 & $22,162,164$ & 14.3 \\
\hline Purchases ... & 103,568 & 4.1 & 218,479 & 8.6 & 70,337 & 2.8 & 417,637 & 16.3 \\
\hline Total & $9,816,486$ & 6.2 & $13,078,108$ & 8.3 & $9,059,372$ & 5.8 & $22,579,801$ & 14.3 \\
\hline \multicolumn{9}{|l|}{ Мемо: } \\
\hline $\begin{array}{l}\text { Number of businesses } \\
\text { in } 1992 \text { (thousands) }\end{array}$ & \multicolumn{2}{|c|}{279.5} & \multicolumn{2}{|c|}{514.1} & \multicolumn{2}{|c|}{318.3} & \multicolumn{2}{|c|}{848.0} \\
\hline $\begin{array}{l}\text { Share of businesses } \\
\text { (percent) } \ldots \ldots \ldots \ldots . . . .\end{array}$ & \multicolumn{2}{|c|}{5.3} & \multicolumn{2}{|c|}{9.8} & \multicolumn{2}{|c|}{6.1} & \multicolumn{2}{|c|}{16.2} \\
\hline Number of farms & & & \multirow{3}{*}{\multicolumn{2}{|c|}{$\begin{array}{r}342.0 \\
16.6\end{array}$}} & \multirow{3}{*}{\multicolumn{2}{|c|}{$\begin{array}{r}113.8 \\
5.5\end{array}$}} & \multirow{2}{*}{\multicolumn{2}{|c|}{158.3}} \\
\hline in 1994 (thousands) & \multirow{2}{*}{\multicolumn{2}{|c|}{$\begin{array}{r}257.0 \\
12.4\end{array}$}} & & & & & & \\
\hline & & & & & & & & \\
\hline $\begin{array}{l}\text { Share of farm revenues } \\
\text { (percent) } \ldots \ldots \ldots \ldots\end{array}$ & & & & & & & & \\
\hline
\end{tabular}

Note. For the states that constitute each census region, see the inside front cover of a recent edition of Statistical Abstract of the United States.

n.a. Not available.

are not evenly distributed across central city neighborhoods, one might expect that the distribution of loans would not be either. To explore this issue, we attempt to identify those central city census tracts that are likely to have high concentrations of small businesses. Based on an assumption that residential areas in close proximity to business districts are likely to be predominantly rental, central city census tracts within each income category were grouped by their rates of home ownership.

The results show that areas with low homeownership rates have significantly more businesses (50 percent to 100 percent more, depending on cen-

example, differences across central city neighborhoods along various dimensions have been noted in Robert B. Avery, Raphael W. Bostic, Paul S. Calem, and Glenn B. Canner, "Changes in the Distribution of Banking Offices," Federal Reserve Bulletin, vol. 83 (September 1997), pp. 707-25.
Source. FFIEC; U.S. Department of Agriculture, Agricultural Statistics, 1995-96; and The State of Small Business, Report of the President, 1995.

sus tract income category) than areas with high homeownership rates, although their population shares are effectively equal, and that lending patterns reflect these differences (table 8.A). Census tracts with low home-ownership rates receive far more small business loans (measured by number or dollar amount) than those with high rates. This relationship holds across all neighborhood income groups. These results show that areas with high concentrations of businesses tend to receive the bulk of small business loans.

In contrast to the distribution of small business loans, most small farm loans are in rural areas (74 percent of all small farm loans). The incomeurbanization pattern observed for small business loans does not generally hold for small farm loans, however. Most small farm loans are made in rural areas regardless of area income (table 8.B). 
8. Small loans to businesses and farms, grouped by neighborhood characteristic and distributed by amount of lending, 1996 A. Loans to businesses

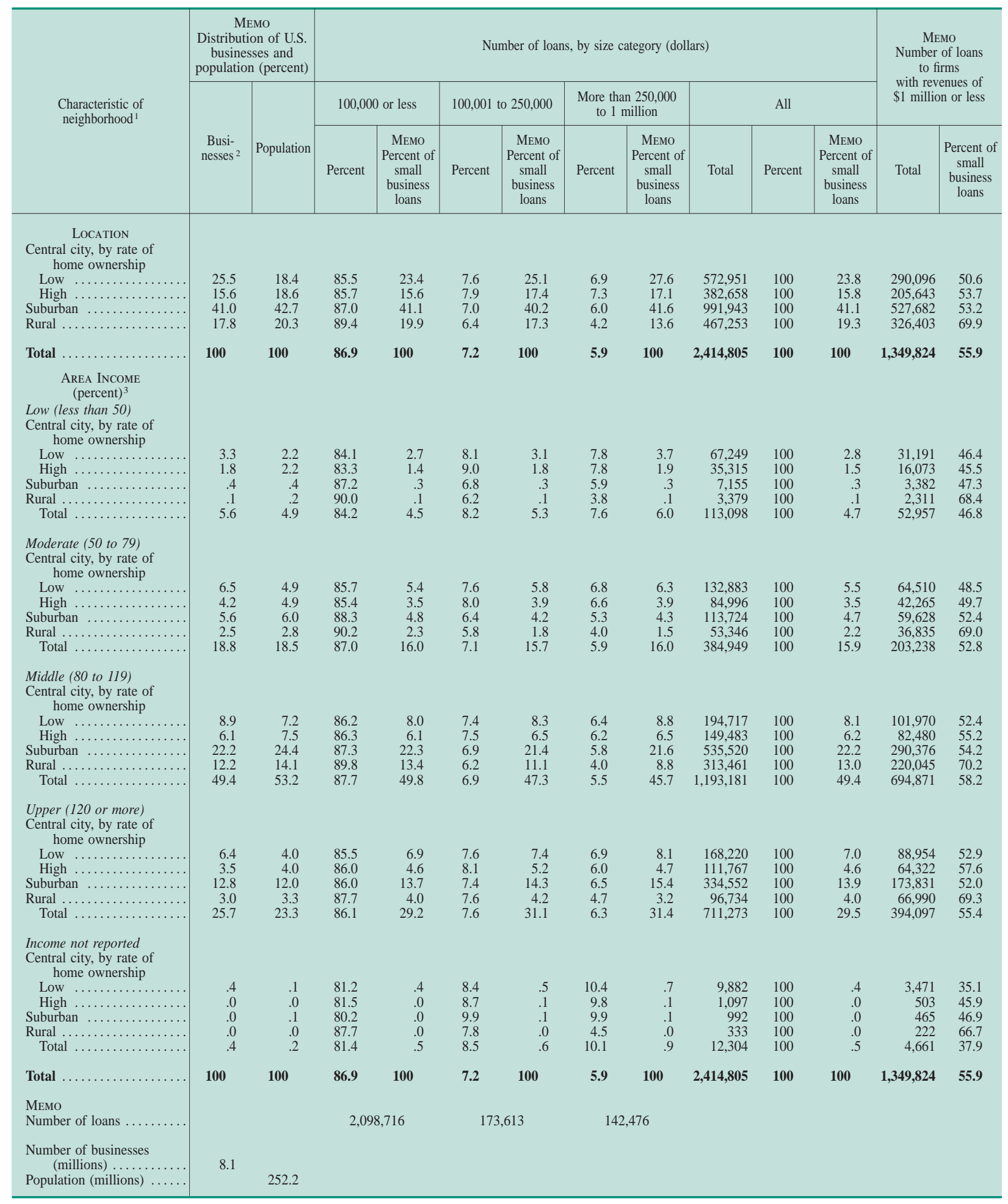


8.-Continued

A.-Continued

\begin{tabular}{|c|c|c|c|c|c|c|c|c|c|c|c|}
\hline \multirow{3}{*}{$\begin{array}{l}\text { Characteristic of } \\
\text { neighborhood }^{1}\end{array}$} & \multicolumn{9}{|c|}{ Amount of loans (thousands of dollars) } & \multirow{2}{*}{\multicolumn{2}{|c|}{$\begin{array}{l}\text { МЕмо } \\
\text { Amount of loans } \\
\text { to firms } \\
\text { with revenues of } \\
\$ 1 \text { million or less }\end{array}$}} \\
\hline & \multicolumn{2}{|c|}{100,000 or less } & \multicolumn{2}{|c|}{100,001 to 250,000} & \multicolumn{2}{|c|}{$\begin{array}{l}\text { More than } 250,000 \\
\text { to } 1 \text { million }\end{array}$} & \multicolumn{3}{|c|}{ All } & & \\
\hline & Percent & $\begin{array}{l}\text { MEMo } \\
\text { Percent of } \\
\text { small } \\
\text { business } \\
\text { loans }\end{array}$ & Percent & $\begin{array}{l}\text { Мемо } \\
\text { Percent of } \\
\text { small } \\
\text { business } \\
\text { loans }\end{array}$ & Percent & $\begin{array}{c}\text { Мемо } \\
\text { Percent of } \\
\text { small } \\
\text { business } \\
\text { loans }\end{array}$ & Total & Percent & $\begin{array}{c}\text { Mемо } \\
\text { Percent of } \\
\text { small } \\
\text { business } \\
\text { loans }\end{array}$ & $\begin{array}{l}\text { Thousands } \\
\text { of dollars }\end{array}$ & $\begin{array}{c}\text { Percent } \\
\text { of small } \\
\text { business } \\
\text { loans }\end{array}$ \\
\hline \multicolumn{12}{|l|}{$\begin{array}{c}\text { LOCATION } \\
\text { Central city, by rate of } \\
\text { home ownership }\end{array}$} \\
\hline Low .............. & 26.8 & 24.2 & 19.6 & 25.4 & 53.6 & 28.0 & $38,770,525$ & 100 & 26.4 & $15,046,521$ & 38.8 \\
\hline High . & 28.3 & 16.3 & 21.0 & 17.4 & 50.7 & 17.0 & $24,793,102$ & 100 & 16.9 & $10,328,805$ & 41.7 \\
\hline Suburban & 28.3 & 39.6 & 20.1 & 40.5 & 51.6 & 41.9 & $60,167,192$ & 100 & 40.8 & $23,997,476$ & 39.9 \\
\hline Rural ... & 36.8 & 19.9 & 21.5 & 16.7 & 41.7 & 13.1 & $23,249,665$ & 100 & 15.8 & $13,210,536$ & 56.8 \\
\hline Total, by location . & 29.3 & 100 & 20.3 & 100 & 50.4 & 100 & $146,980,484$ & 100 & 100 & $62,583,338$ & 42.6 \\
\hline \multicolumn{12}{|l|}{$\begin{array}{l}\text { AREA INCOME } \\
\text { (percent })^{3}\end{array}$} \\
\hline \multicolumn{12}{|l|}{$\begin{array}{l}\text { Low (less than } 50 \text { ) } \\
\text { Central city, by rate of } \\
\text { home ownership }\end{array}$} \\
\hline Low .............. & 24.8 & 2.9 & 19.3 & 3.2 & 55.9 & 3.7 & $4,957,683$ & 100 & 3.4 & $1,749,976$ & 35.3 \\
\hline High . & 24.4 & 1.5 & 21.1 & 1.9 & 54.5 & 1.9 & $2,617,885$ & 100 & 1.8 & 884,280 & 33.8 \\
\hline Suburban & 27.7 & .3 & 20.3 & .3 & 52.0 & .3 & 429,503 & 100 & .3 & 155,088 & 36.1 \\
\hline Rural ... & 38.2 & .1 & 21.6 & .1 & 40.2 & .1 & 158,946 & 100 & .1 & 96,465 & 60.7 \\
\hline Total & 25.1 & 4.8 & 20.0 & 5.5 & 54.9 & 6.1 & $8,164,017$ & 100 & 5.6 & $2,885,809$ & 35.3 \\
\hline \multicolumn{12}{|l|}{$\begin{array}{l}\text { Moderate (50 to } 79) \\
\text { Central city, by rate of } \\
\text { home ownership }\end{array}$} \\
\hline Low $\ldots \ldots \ldots \ldots$ & 26.9 & 5.6 & 19.8 & 5.9 & 53.3 & 6.4 & $8,910,232$ & 100 & 6.1 & $3,381,621$ & 38.0 \\
\hline High . & 27.3 & 3.6 & 20.7 & 3.9 & 52.0 & 4.0 & $5,650,967$ & 100 & 3.8 & $2,053,835$ & 36.3 \\
\hline Suburban & 30.7 & 4.5 & 19.7 & 4.2 & 49.7 & 4.3 & $6,381,503$ & 100 & 4.3 & $2,496,672$ & 39.1 \\
\hline Rural ... & 36.8 & 2.2 & 20.5 & 1.7 & 42.8 & 1.5 & $2,537,436$ & 100 & 1.7 & $1,425,166$ & 56.2 \\
\hline Total & 29.1 & 15.9 & 20.0 & 15.7 & 50.9 & 16.1 & $23,480,138$ & 100 & 16.0 & $9,357,294$ & 39.9 \\
\hline \multicolumn{12}{|l|}{$\begin{array}{l}\text { Middle ( } 80 \text { to } 119) \\
\text { Central city, by rate of } \\
\text { home ownership }\end{array}$} \\
\hline Low $\ldots \ldots \ldots \ldots \ldots$ & 27.7 & 8.1 & 19.9 & 8.3 & 52.4 & 8.9 & $12,526,947$ & 100 & 8.5 & $5,088,239$ & 40.6 \\
\hline High . & 28.8 & 6.3 & 20.5 & 6.4 & 50.8 & 6.4 & $9,385,430$ & 100 & 6.4 & $4,026,121$ & 42.9 \\
\hline Suburban & 29.1 & 21.3 & 20.3 & 21.4 & 50.7 & 21.7 & $31,631,288$ & 100 & 21.5 & $12,734,763$ & 40.3 \\
\hline Rural .... & 37.6 & 13.3 & 21.1 & 10.8 & 41.3 & 8.5 & $15,215,257$ & 100 & 10.4 & $8,578,759$ & 56.4 \\
\hline Total & 30.7 & 49.0 & 20.4 & 47.0 & 48.9 & 45.4 & $68,758,922$ & 100 & 46.8 & $30,427,882$ & 44.3 \\
\hline \multicolumn{12}{|l|}{$\begin{array}{l}\text { Upper (120 or more) } \\
\text { Central city, by rate of } \\
\text { home ownership }\end{array}$} \\
\hline Low $\ldots \ldots \ldots \ldots$ & 27.2 & 7.3 & 19.5 & 7.5 & 53.3 & 8.3 & $11,484,547$ & 100 & 7.8 & $4,614,103$ & 40.2 \\
\hline High ... & 30.2 & 4.9 & 21.9 & 5.2 & 47.9 & 4.6 & $7,045,946$ & 100 & 4.8 & $3,336,311$ & 47.4 \\
\hline Suburban & 26.7 & 13.4 & 20.0 & 14.5 & 53.3 & 15.6 & $21,633,230$ & 100 & 14.7 & $8,588,377$ & 39.7 \\
\hline Rural .... & 34.5 & 4.3 & 22.9 & 4.1 & 42.6 & 3.1 & $5,318,300$ & 100 & 3.6 & $3,099,475$ & 58.3 \\
\hline Total & 28.3 & 29.9 & 20.5 & 31.2 & 51.2 & 31.5 & $45,482,023$ & 100 & 30.9 & $19,638,266$ & 43.2 \\
\hline \multicolumn{12}{|l|}{$\begin{array}{c}\text { Income not reported } \\
\text { Central city, by rate of } \\
\text { home ownership }\end{array}$} \\
\hline Low $\ldots \ldots \ldots \ldots$ & 19.7 & .4 & 16.7 & .5 & 63.6 & .8 & 891,116 & 100 & .6 & 212,582 & 23.9 \\
\hline High . & 21.4 & .0 & 19.0 & 1 & 59.5 & .1 & 92,874 & 100 & .1 & 28,258 & 30.4 \\
\hline Suburban & 18.2 & .0 & 19.7 & .1 & 62.1 & .1 & 91,668 & 100 & .0 & 22,576 & 24.6 \\
\hline Rural ... & 40.1 & .0 & 23.0 & .0 & 36.9 & .0 & 19,726 & 100 & .0 & 10,671 & 54.1 \\
\hline Total & 18.0 & .5 & 17.2 & .6 & 62.7 & .9 & $1,095,384$ & 100 & .7 & 274,087 & 25.0 \\
\hline Total & 29.3 & 100 & 20.3 & 100 & 50.4 & 100 & $146,980,484$ & 100 & 100 & $62,583,338$ & 42.6 \\
\hline \multicolumn{12}{|l|}{ Мемо } \\
\hline $\begin{array}{c}\text { Dollar amount of loans } \\
\text { (thousands) } \ldots \ldots \ldots\end{array}$ & 43,0 & ,437 & 29,8 & 3,065 & 74, & 982 & & & & & \\
\hline
\end{tabular}


8.-Continued

B. Loans to farms

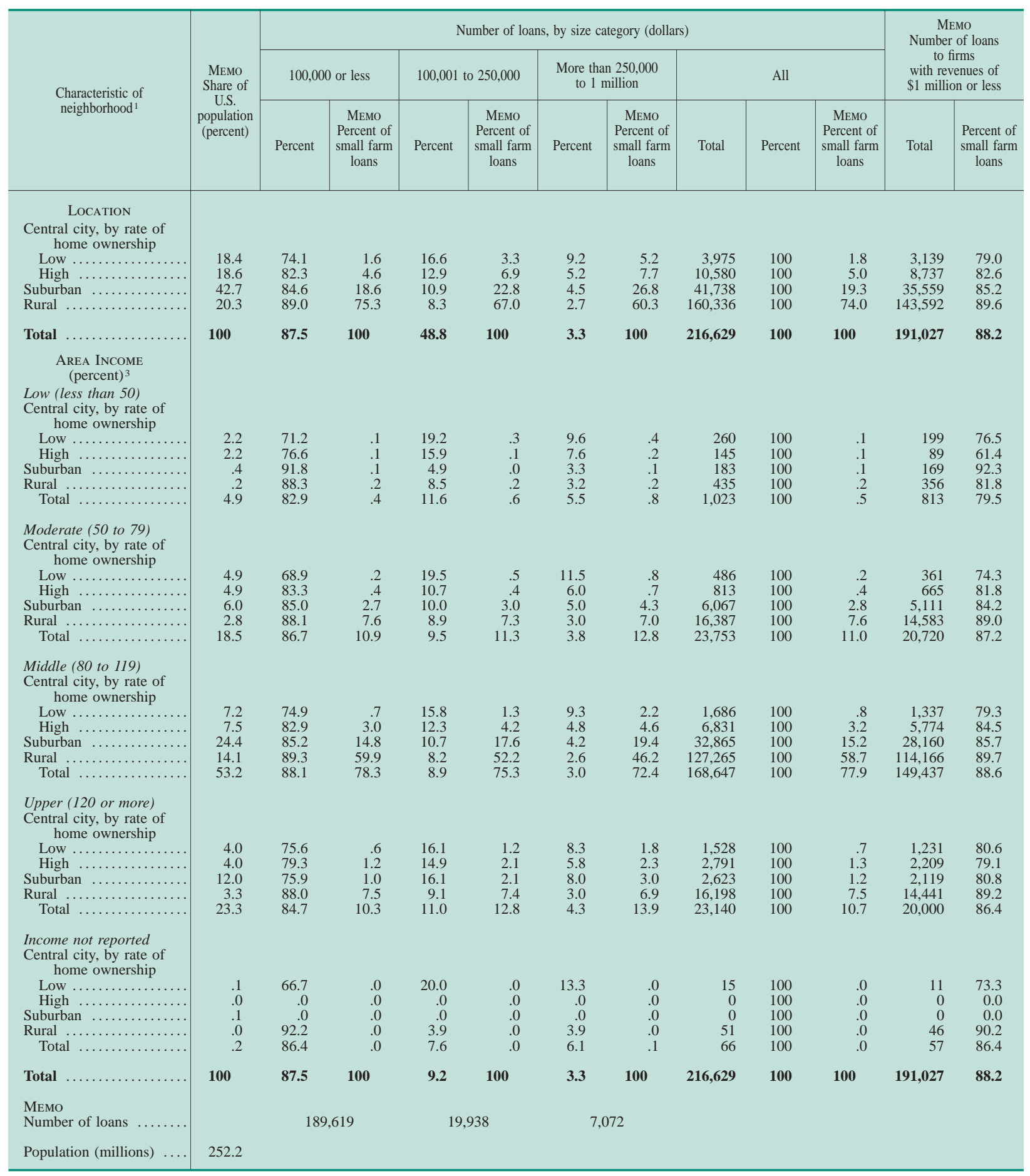


8.-Continued

B-Continued

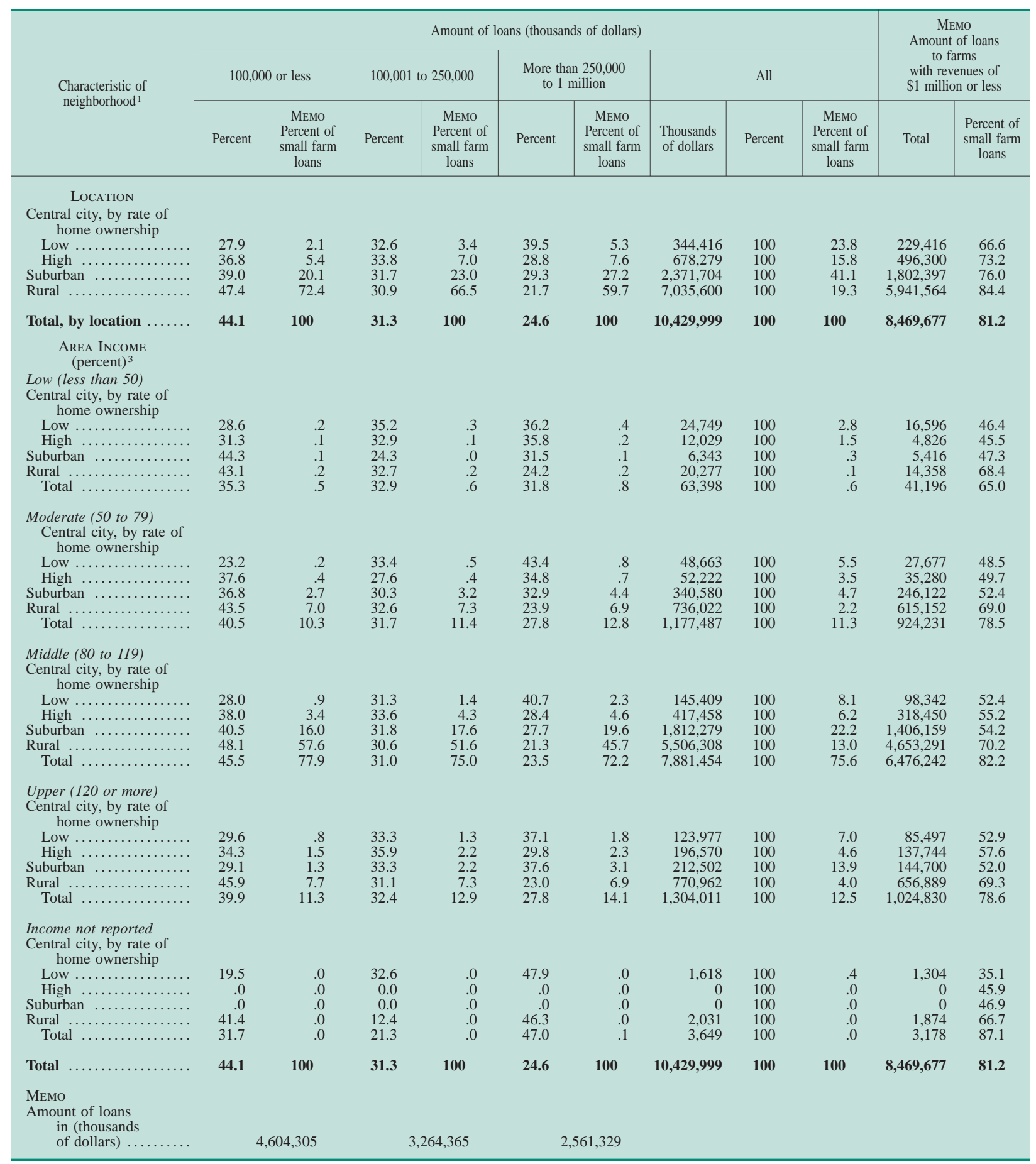

1. Census tracts in central city locations are grouped by home-ownership 3. For census tracts in central cities and suburbs, which together constitute metropolitan statistical areas (MSAs), percentage is of MSA median. For census tracts in rural areas, percentage is of nonmetropolitan areas of state median.

median home-ownership rate for all central city census tracts; a high rate is defined as being above the median.

2. Data on share of businesses derived from information provided by the SOURCE. FFIEC.

Office of the Comptroller of the Currency. The shares are calculated on a slightly smaller subset of the census tracts than those included in the CRA data. 
Lending to Low- and Moderate-Income

Neighborhoods by Institutions

On average, institutions covered by the CRA reporting requirements extended about 5 percent of their small business loans in low-income census tracts and about 16 percent of their loans in moderate-income tracts (table 8.A). However, lending activity varies greatly across lending institutions because of a number of different factors, including the characteristics of the local service areas and market conditions. To provide a sense of this diversity, we calculated the share of each institution's lending that occurred in low- and moderate-income census tracts and ranked institutions by these shares. This procedure used all small business lending in 1996 for each institution as a reference point, which differs from analytical procedures used by CRA examiners that focus on activity within specific assessment areas. A large proportion of institutions (39.8 percent) report that their small business lending in low-income areas makes up a very small share (less than 1 percent) of their newly originated or purchased loans. By contrast, only 8.8 percent of these institutions report that their small business lending in moderate-income areas makes up such a small share of their small business lending activity (table 9).

\section{Community Development Lending}

Besides information about small business and small farm lending, institutions covered by the CRA data reporting requirements also disclose the number and dollar amount of their community development loans. Community development loans are defined in the regulation as loans whose primary purpose is community development and which have not been reported elsewhere as a home purchase, small business, small farm, or consumer loan. ${ }^{28}$ Examples include loans to local lending consortiums and local nonprofit organizations.

For 1996, 32,677 community development loans totaling $\$ 17.7$ billion were reported (table 10). The average community development loan, at $\$ 542,000$, was far larger than the average small business loan of $\$ 61,000$ reported in the CRA data.

Among CRA reporters, 58 percent of the commercial banks and 48 percent of the savings associations extended community development loans in 1996 (derived from table 10). Of the total number of

28. For more details see the Federal Reserve's April 24, 1995, press release.

9. Institutions that lend to small businesses in low- or moderate-income neighborhoods, grouped by neighborhood income of the borrowers and distributed by the share of such loans in the institutions's total lending to small businesses, 1996 Percent

\begin{tabular}{|c|c|c|c|c|c|c|}
\hline \multirow{2}{*}{$\begin{array}{l}\text { Share of small business lending } \\
\text { (percent) })^{1}\end{array}$} & \multicolumn{3}{|c|}{ By number of loans } & \multicolumn{3}{|c|}{ By amount of loans } \\
\hline & Low income & $\begin{array}{l}\text { Moderate } \\
\text { income }\end{array}$ & $\begin{array}{l}\text { Low and } \\
\text { moderate income }\end{array}$ & Low income & $\begin{array}{l}\text { Moderate } \\
\text { income }\end{array}$ & $\begin{array}{l}\text { Low and } \\
\text { moderate income }\end{array}$ \\
\hline Less than 1 & 39.8 & 8.8 & 7.2 & 40.7 & 10.1 & 8.7 \\
\hline 1 to $2 \ldots \ldots$ & 8.6 & 3.3 & 3.3 & 8.2 & 3.4 & 2.4 \\
\hline 2 to $3 \ldots$ & 8.2 & 3.4 & 2.5 & 7.2 & 2.9 & 2.8 \\
\hline 3 to $4 \ldots$ & 7.1 & 2.8 & 2.7 & 6.6 & 3.0 & 2.1 \\
\hline 4 to 5 . & 6.6 & 2.7 & 2.0 & 4.8 & 3.3 & 2.1 \\
\hline 5 to $6 \ldots$ & 5.6 & 2.5 & 1.8 & 6.0 & 3.2 & 2.3 \\
\hline 6 to 7 & 4.8 & 3.7 & 2.1 & 4.5 & 2.4 & 2.0 \\
\hline 7 to 8 & 4.6 & 3.2 & 1.9 & 4.3 & 3.9 & 2.8 \\
\hline 8 to 9. & 3.2 & 3.8 & 2.9 & 2.5 & 3.6 & 2.1 \\
\hline 9 to 10 . & 1.9 & 3.9 & 2.7 & 2.7 & 3.8 & 1.4 \\
\hline 10 to $15 \ldots$ & 5.8 & 21.5 & 14.0 & 8.0 & 19.4 & 14.5 \\
\hline More than 15 & 3.8 & 40.5 & 56.8 & 4.5 & 40.9 & 56.7 \\
\hline Total & 100 & 100 & 100 & 100 & 100 & 100 \\
\hline
\end{tabular}

Note. Excludes 151 lenders, about 8 percent of all lenders, that reported fewer than 25 small business loans.

Low-income neighborhoods are defined as census tracts with a median family income of less than 50 percent of the median family income of the tract's metropolitan statistical area (MSA) or, if the tract is not in an MSA, less than 50 percent of the entire nonmetropolitan portion of the state. The median income of moderate-income neighborhoods is 50 percent to 79 percent of the median income of the broader area.
1. Share is the percentage of a lender's total small business originations and purchases of loans to borrowers that are in the neighborhood income category. The share is based on all reported loans for which neighborhood income data were available.

SOURCE. FFIEC. 
10. Community development lending, 1996

\begin{tabular}{|c|c|c|c|c|c|c|c|c|}
\hline \multirow{3}{*}{$\begin{array}{l}\text { Type and asset size of lender } \\
\text { (millions of dollars) }\end{array}$} & \multicolumn{2}{|c|}{ Number of loans } & \multicolumn{2}{|c|}{$\begin{array}{l}\text { Amount of loans } \\
\text { (thousands of dollars) }\end{array}$} & \multicolumn{4}{|c|}{ Мемо: CRA reporters } \\
\hline & \multirow{2}{*}{ Total } & \multirow{2}{*}{ Percent } & \multirow{2}{*}{ Total } & \multirow{2}{*}{ Percent } & \multirow{2}{*}{ Number } & \multirow{2}{*}{ Percentage } & \multicolumn{2}{|c|}{$\begin{array}{c}\text { Community development } \\
\text { loans }\end{array}$} \\
\hline & & & & & & & $\begin{array}{l}\text { Number } \\
\text { extending }\end{array}$ & $\begin{array}{l}\text { Percentage } \\
\text { extending }\end{array}$ \\
\hline Commercial banks & & & & & & & & \\
\hline Less than $100 \ldots$. & 655 & 2.0 & 106,547 & .6 & 208 & 10.0 & 78 & 6.7 \\
\hline 100 to $249 \ldots$. & 1,634 & 5.0 & 240,605 & 1.4 & 293 & 14.1 & 128 & 11.1 \\
\hline 250 to $999 \ldots$ & 10,181 & 31.2 & $2,146,720$ & 12.1 & 690 & 33.2 & 417 & 36.1 \\
\hline 1,000 or more & 13,523 & 41.4 & $12,218,553$ & 69.0 & 373 & 17.9 & 285 & 24.7 \\
\hline Total $\ldots . .$. & 25,993 & 79.5 & $14,712,425$ & 83.1 & 1,564 & 75.3 & 908 & 78.5 \\
\hline $\begin{array}{l}\text { Memo: Lending by } \\
\text { commercial bank affiliates . }\end{array}$ & 211 & .8 & 423,976 & 2.9 & & & 28 & 3.1 \\
\hline Savings associations & & & & & & & & \\
\hline Less than $100 \ldots \ldots$. & 64 & .2 & 46,799 & .3 & 9 & .4 & 2 & .2 \\
\hline 100 to $249 \ldots \ldots$ & 12 & $*$ & 14,906 & .1 & 16 & .8 & 4 & .3 \\
\hline 250 to $999 \ldots \ldots \ldots$ & 2,181 & 6.7 & 764,314 & 4.3 & 346 & 16.7 & 151 & 13.1 \\
\hline 1,000 or more $\ldots \ldots \ldots \ldots \ldots \ldots$ & 4,427 & 13.5 & $2,169,717$ & 12.3 & 143 & 6.9 & 91 & 7.9 \\
\hline Total $\ldots \ldots \ldots \ldots$ & 6,684 & 20.5 & $2,995,736$ & 16.9 & 514 & 24.7 & 248 & 21.5 \\
\hline $\begin{array}{l}\text { Memo: Lending by } \\
\text { savings association affiliates }\end{array}$ & 482 & 7.2 & 139,693 & 4.7 & $\cdots$ & $\cdots$ & 6 & 2.4 \\
\hline All & 32,677 & 100 & $17,708,161$ & 100 & 2,078 & 100 & 1,156 & 100 \\
\hline Мемо: Lending by all affiliates & 693 & 2.1 & 563,669 & 3.2 & & $\ldots$ & 34 & 2.9 \\
\hline
\end{tabular}

community development loans, commercial banks extended nearly 80 percent, with large commercial banks and savings associations (assets of $\$ 1$ billion or more) extending the majority (55 percent). These large lenders tended to make larger loans, as these institutions accounted for 81 percent of the community development lending measured in dollars. Affiliates of reporting institutions extended relatively few ( 2 percent) of the community development loans.

\section{CONCLUDING THOUGHTS}

The new CRA data on small business, small farm, and community development lending provide opportunities to gauge the flow of credit to communities throughout the country. Analysis of the data suggests that, overall, the number and dollar amount of small business loans originated and purchased by CRAreporting institutions are distributed in a manner that parallels the distribution of population and businesses across the country. This relationship holds across census regions and across neighborhoods with differ- ing incomes and degrees of urbanization. The analysis also reveals considerable variation among individual lenders in the distribution of their small business lending across neighborhood income categories. By contrast, the data show that the distribution of small farm lending is quite different from the distribution of the population-most small farm loans were extended in rural areas, which have relatively small populations. The distribution of small farm lending does closely resemble the distribution of small farms across census regions, however.

Regarding use of the data to gauge the performance of lending institutions in meeting their CRA obligation, it must be emphasized that the geographic distribution of an institution's lending will be greatly influenced by the types of credit products it offers, the types of businesses in its local communities, the competitive environment it faces, and the characteristics of the communities it serves. As a result, the broad patterns of lending for all institutions found in the data may not reflect those of a single institution or group of institutions in any given neighborhood or local market. 